\title{
Analysis of phytoplankton distribution and community structure in the German Bight with respect to the different size classes
}

\author{
Jochen Wollschläger ${ }^{\text {a,* }}$, Karen Helen Wiltshire ${ }^{c}$, Wilhelm Petersen ${ }^{a}$, Katja Metfies ${ }^{b}$ \\ ${ }^{a}$ Helmholtz-Zentrum Geesthacht, Centre for Materials and Coastal Research, Institute of Coastal Research, Max-Planck-Str. 1, 21502 Geesthacht, Germany \\ ${ }^{\mathrm{b}}$ Alfred Wegener Institute Helmholtz Centre for Polar and Marine Research, Am Handelshafen 12, 27570 Bremerhaven, Germany \\ c Alfred Wegener Institute, Biologische Anstalt Helgoland, Kurpromenade, 27498 Helgoland, Germany
}

\section{A R T I C L E I N F O}

\section{Article history:}

Received 19 June 2014

Received in revised form 9 January 2015

Accepted 10 February 2015

Available online 18 February 2015

\section{Keywords:}

Phytoplankton

Biodiversity

North Sea

Flow cytometry

Molecular sensing

Microscopy

\begin{abstract}
A B S T R A C T
Investigation of phytoplankton biodiversity, ecology, and biogeography is crucial for understanding marine ecosystems. Research is often carried out on the basis of microscopic observations, but due to the limitations of this approach regarding detection and identification of picophytoplankton $(0.2-2 \mu \mathrm{m})$ and nanophytoplankton $(2-20 \mu \mathrm{m})$, these investigations are mainly focused on the microphytoplankton $(20-200 \mu \mathrm{m})$. In the last decades, various methods based on optical and molecular biological approaches have evolved which enable a more rapid and convenient analysis of phytoplankton samples and a more detailed assessment of small phytoplankton. In this study, a selection of these methods (in situ fluorescence, flow cytometry, genetic fingerprinting, and DNA microarray) was placed in complement to light microscopy and HPLC-based pigment analysis to investigate both biomass distribution and community structure of phytoplankton. As far as possible, the size classes were analyzed separately. Investigations were carried out on six cruises in the German Bight in 2010 and 2011 to analyze both spatial and seasonal variability.

Microphytoplankton was identified as the major contributor to biomass in all seasons, followed by the nanophytoplankton. Generally, biomass distribution was patchy, but the overall contribution of small phytoplankton was higher in offshore areas and also in areas exhibiting higher turbidity. Regarding temporal development of the community, differences between the small phytoplankton community and the microphytoplankton were found. The latter exhibited a seasonal pattern regarding number of taxa present, alphaand beta-diversity, and community structure, while for the nano- and especially the picophytoplankton, a general shift in the community between both years was observable without seasonality. Although the reason for this shift remains unclear, the results imply a different response of large and small phytoplankton to environmental influences.
\end{abstract}

(c) 2015 Elsevier B.V. All rights reserved.

\section{Introduction}

Microalgae are the main primary producers in marine ecosystems and constitute the basis of the marine food web. Although representing less than $1 \%$ of global biomass, they are responsible for roughly $50 \%$ of global carbon fixation and are therefore a crucial factor in the carbon cycle (Field et al., 1998). Coasts and shelf seas in particular are highly productive areas fostered by their comparably low water depth and higher nutrient input by upwelling or adjacent rivers. Due to this productivity and other benefits, $40 \%$ of the world's population lives within $100 \mathrm{~km}$ distance from the coast (IOC/UNESCO, 2011), putting pressure on the ecosystem because of e.g., increased pollution and eutrophication. These stressors as well as climate change effects will probably have an influence on the phytoplankton and changes within its

\footnotetext{
* Corresponding author.

E-mail address: Jochen.Wollschlaeger@hzg.de (J. Wollschläger).
}

community are likely to propagate also to higher trophic levels. In order to get track of potential changes and to relate them eventually to observations made on other parts of the marine ecosystem, it is important to investigate phytoplankton development comprehensively both in terms of spatiotemporal distribution and biodiversity. Information on biodiversity is of special importance, since its loss can potentially further reduce the ability of the ecosystem to cope with environmental changes or human induced stress (Yachi and Loreau, 1999).

The North Sea is an example for a highly utilized coastal area (Ducrotoy et al., 2000), and a lot of knowledge has been collected about the structure and variability of its phytoplankton community, either due to long lasting time series or due to occasional research cruises (Reid et al., 1990; Tillmann and Rick, 2003; Wiltshire et al., 2010). Information is available regarding seasonal succession patterns (Hagmeier and Bauerfeind, 1990; Reid et al., 1990), response to environmental factors (Freund et al., 2012; Gillbricht, 1988; Hickel, 1998; Schlüter et al., 2012), and biodiversity (Hoppenrath, 2004; Hoppenrath et al., 2007; Wiltshire and Dürselen, 2004). However, 
since most of this information is based on microscopic observation, it covers mainly the microphytoplankton (20-200 $\mu \mathrm{m})$. The taxonomical resolution of the information available for smaller phytoplankton is rare (Knefelkamp, 2009), because it is more difficult to count microscopically and often lacks morphological features for a reliable identification. Approaches based on electron microscopy (e.g., Novarino et al., 1997) require too much effort to be used on a larger scale and have often problems similar to light microscopy regarding species identification. However, for a thorough understanding of phytoplankton ecology, information on nanophytoplankton $(2-20 \mu \mathrm{m})$ and picophytoplankton $(0.2-2 \mu \mathrm{m})$ of comparable quality to the information available for microphytoplankton would be advantageous.

In the present study, the spatial and temporal variability of phytoplankton community structure and biomass was assessed including all three phytoplankton size classes as far as possible. A set of various complementary methods was used, since the whole community is hardly accessible by one method alone (Peperzak, 2010; Stehouwer et al., 2013). This included light microscopy, HPLC-based phytoplankton pigment determination, in situ chlorophyll- $a$ fluorescence measurements, flow cytometry, molecular fingerprinting, and DNA microarray analyses (Table 1).

With this suite of methods, in the North Sea almost the whole German Bight was extensively sampled over several seasons for two years (2010 and 2011). This allowed the investigation of the phytoplankton community with respect to seasonal, but also spatial differences. Thus, the provided data might be a valuable addition to the existing datasets which are mostly obtained in smaller areas or even on single spots.

\section{Materials and methods}

\subsection{Study area and sampling}

Data were obtained on six cruises conducted with the research vessel "Heincke" during 2010 (May, July, September) and 2011 (April, June, September) in the German Bight (North Sea). Both transect as well as station measurements were performed. Due to weather conditions, the order of stations was not always the same and in September, the most offshore stations could not be sampled. At each cruise, "extra" stations were integrated along the transect lines between the regular stations, but their frequency and position varied between the cruises. Continuous measurements were carried out during the whole cruise duration at a depth of approx. $4 \mathrm{~m}$. On stations, water samples for laboratory analyses were taken from a comparable depth using a sampling rosette (SBE 32, Sea-Bird Electronic, Inc.) equipped with seven $9 \mathrm{~L}$ "Niskin" bottles. The samples were carefully mixed and aliquots were processed for the methods described below.

\subsection{Discrete measurements of phytoplankton pigments and total suspended matter}

Phytoplankton pigment concentration was measured by High Performance Liquid Chromatography (HPLC) after the method of Zapata et al. (2000). Water samples (1-5 L) were filtered through pre- combusted GF/F filters (Whatman, USA, Ø $47 \mathrm{~mm}$ ). Afterwards, the filters were shock-frozen in liquid nitrogen and stored at $-80^{\circ} \mathrm{C}$. In the laboratory, pigments were extracted from the filters by incubation with $100 \%$ acetone for $24 \mathrm{~h}$ at $-30{ }^{\circ} \mathrm{C}$. The extracts were transferred into $2 \mathrm{~mL}$ glass vials and simultaneously cleaned from particles by passing them through $0.2 \mu \mathrm{m}$ syringe filters (regenerated cellulose, Spartan, A13). Separation and analysis of chlorophyll- $a$ (chl- $a$ ) and groupspecific marker pigments was carried out by a HPLC system from JASCO (Japan). Contribution of diatoms, dinophytes, cryptophytes, prymnesiophytes, and prasinophytes to total chl- $a$ was estimated using the CHEMTAX software (Mackey et al., 1996) with initial pigment ratios derived from Schlüter et al. (2000). See SUP. 1 for details.

Concentration of total suspended matter (TSM) was determined by filtration of 1-8 L of the water sample through pre-combusted, prewashed and pre-weighted GF/F filters (Whatman, USA, Ø $47 \mathrm{~mm}$ ). Previous to usage, the filters were wet with purified water to avoid saturation with sea water and to reduce the amount of salt that cannot be washed out of the filter after filtration. To correct for still remaining salt at each cruise filtered seawater was also applied to empty filters. Their average salt induced weight increase was then subtracted from all samples of the particular cruise before calculating total suspended matter concentration; see Stavn et al. (2009) for details. Additionally, manual water turbidity measurements were conducted at the stations using a Hach 2100P ISO turbidimeter (Hach, USA).

\subsection{Continuous measurements of abiotic parameters and chl-a}

Continuous measurements (at $1 \mathrm{~min}$ intervals) of temperature, salinity, chromophoric dissolved organic matter (CDOM), turbidity, and chlorophyll- $a$ fluorescence were performed using a FerryBox system as described in Petersen et al. (2011) installed aboard the ship. The sensors mounted in the FerryBox are listed in SUP. 2. TSM and chl- $a$ concentrations were calculated on the basis of continuous turbidity and chl- $a$ fluorescence measurements using the coefficients given in Table 2 . They are the result of linear regressions between the discrete TSM and chl- $a$ measurements obtained at the stations and values for the corresponding optical proxy extracted from the respective continuous data set.

Concentrations of nitrate and phosphate were measured approx. every 50 min using a Systea $\mu$ Mac nutrient analyzer (Systea, Italy) attached to a bypass of the FerryBox. Sample water for the nutrient analyzer was filtered by a cross-flow filter (MiniKros, pore size $0.2 \mu \mathrm{m}$, Spectrum Laboratories, USA) previously to analysis. In between the measurements, values for the whole time of the respective cruise were interpolated. For a correction of the field measurements, discrete water samples were taken behind the cross-flow filter, stored at $-20{ }^{\circ} \mathrm{C}$, and analyzed in the laboratory for nitrate and phosphate using an AutoAnalyzer 3 (Bran + Luebbe, Germany) and the methods from Grasshoff et al. (1983).

\subsection{Microscopic cell counts}

At each station, $100 \mathrm{~mL}$ of seawater was filled into brown glass bottles, fixed with $0.5 \mathrm{~mL}$ Lugol's solution, and stored at $4-8{ }^{\circ} \mathrm{C}$ until

Table 1

Overview of methods used.

\begin{tabular}{|c|c|c|}
\hline Method & Target & Parameter derived \\
\hline Microscopy & Microphytoplankton (>20 $\mu \mathrm{m})$ & Cell counts and sizes of single taxa \\
\hline Pigment analysis (HPLC) & Community as a whole & Contribution of phytoplankton classes \\
\hline in situ fluorescence & Community as a whole & Bulk biomass distribution (as chl- $a$ ) \\
\hline \multirow{2}{*}{ Flow cytometry } & Nanophytoplankton $(2-20 \mu \mathrm{m})$ & Cell counts and biomass proxies \\
\hline & Picophytoplankton $(0.2-2 \mu \mathrm{m})$ & \\
\hline Molecular fingerprinting (ARISA) & Community as a whole & Community structure \\
\hline Microarray & $\begin{array}{l}\text { Selected clades of nanophytoplankton }(2-20 \mu \mathrm{m}) \\
\text { and picophytoplankton }(0.2-2 \mu \mathrm{m})\end{array}$ & Presence of investigated clades \\
\hline
\end{tabular}


Table 2

Coefficients obtained from linear regression used for the conversion of chl- $a$ fluorescence into chl- $a$ concentration and turbidity into TSM concentration, respectively. The equation used for conversion was parameter $=($ optical proxy value - offset $) /$ slope.

\begin{tabular}{|c|c|c|c|c|c|c|}
\hline & Cruise & Slope & Slope error & Offset & Offset Error & $\mathrm{R}^{2}$ \\
\hline \multirow[t]{6}{*}{ Chl- $a$} & May 2010 & 0.35 & 0.03 & 0.88 & 0.34 & 0.94 \\
\hline & July $2010^{\mathrm{a}}$ & 149.42 & 20.29 & 136.19 & 77 & 0.77 \\
\hline & September 2010 & 0.5 & 0.08 & 0.23 & 0.34 & 0.68 \\
\hline & April 2011 & 0.49 & 0.05 & 1.13 & 0.16 & 0.76 \\
\hline & June 2011 & 0.44 & 0.04 & 1.17 & 0.14 & 0.81 \\
\hline & September 2011 & 0.36 & 0.05 & 1.25 & 0.15 & 0.7 \\
\hline \multirow[t]{6}{*}{ TSM } & May 2010 & 0.43 & 0.03 & -0.62 & 0.17 & 0.97 \\
\hline & July $2010^{\mathrm{a}}$ & 0.36 & 0.02 & 0.28 & 0.04 & 0.93 \\
\hline & September 2010 & 0.34 & 0.03 & 0.97 & 0.35 & 0.87 \\
\hline & April 2011 & 0.45 & 0.01 & 0.68 & 0.04 & 0.98 \\
\hline & June 2011 & 0.28 & 0.03 & 0.81 & 0.1 & 0.77 \\
\hline & September 2011 & 0.38 & 0.01 & 1.16 & 0.06 & 0.99 \\
\hline
\end{tabular}

${ }^{a}$ In this cruise, the continuous measurements were conducted by the ECO FLNTU sensor instead of the SCUFA-II.

analysis (Utermöhl, 1958). Normally, $50 \mathrm{~mL}$ of sample was allowed to settle for $24 \mathrm{~h}$, but in case of increased amounts of particulate matter, only $25 \mathrm{~mL}$ of sample was analyzed. Microphytoplankton cells ( $>20 \mu \mathrm{m}$ in largest dimension) were counted and identified to species or genus, but at least to class level using an inverted microscope (Olympus IX 51 , Olympus, Japan), phase contrast and $100 \times$ or $200 \times$ magnification. No regular replicate counting of samples was performed, since in most cases a single count can be considered sufficient (Lund et al., 1958). Random re-counts of single species in different samples showed that the counting error was in average $11 \%$ (with the highest value $22 \%$ ) in the present study. Biovolume of autotrophic cells was calculated using the mean values of cell dimensions recorded from - if possible - at least 25 individuals per taxon and the equations given in Hillebrand et al. (1999). After correction for the effect of fixation (Montagnes et al., 1994), it was converted into carbon using the appropriate equations given in Menden-Deuer and Lessard (2000). In cases where the dimensions of a certain taxon could not be measured for a particular cruise, the average cell dimensions of this taxon from the other cruises were used instead for calculation purposes. The error introduced thereby was considered to be smaller than the error introduced by a complete omission of the particular taxon from the cruise. Diversity of the samples was estimated by species accumulation curves and by calculation of the 'Simpson Index' (Magurran, 2004).

\subsection{Flow cytometry}

For flow cytometry analyses, $3 \mathrm{~mL}$ samples of seawater were fixed with glutaraldehyde ( $0.4 \%$ final concentration), incubated for $15 \mathrm{~min}$, shock-frozen in liquid nitrogen, and stored at $-20{ }^{\circ} \mathrm{C}$. Sample analysis was carried out using a FACSCalibur (BD Biosciences, USA) or an Accuri C6 Flow Cytometer (BD, Biosciences, USA). Autofluorescence of phytoplankton was excited by blue light ( $488 \mathrm{~nm}$ ) emitted by a $20 \mathrm{~mW}$ laser. Isolation of eukaryotic nano- and picophytoplankton was performed manually by visual inspection of 2D-density plots (orange vs. red emission and green emission vs. sidescatter, respectively). For intercalibration between samples, yellow-green fluorescent latex beads ( $0.94 \mu \mathrm{m}$ diameter, Polysciences, USA) were used and served also as reference for the normalization of cellular optical properties. In case of the FACSCalibur, TruCount beads (Becton Dickinson, USA) were used for absolute sample volume calibration. Parameters obtained for both phytoplankton fractions were cell counts, average cell size (based on side scatter) as well as red and orange fluorescence intensity. Estimations of biovolume values the members of the nano- and picophytoplankton size classes were made using the mean diameter of the respective size class for the particular station under the assumption of a spherical shape of the cells. Carbon calculation was performed as described for microphytoplankton (see Section 2.4) using the equation for the non-diatom phytoplankton.

\subsection{Molecular biological analyses}

Samples for genetic analyses of the phytoplankton community were obtained by filtration of $400-1500 \mathrm{~mL}$ seawater onto $0.2 \mu \mathrm{m}$ Isopore GTTP membrane filters (Millipore, Germany). Subsequently, filters were shock-frozen in liquid nitrogen and stored at $-20^{\circ} \mathrm{C}$. Genomic DNA was isolated from the filters using an E.Z.N.A. Plant DNA Mini Kit (Omega Bio-Tek, USA) according to the instructions of the manufacturer. Concentration of DNA in the obtained extracts was determined with a NanoDrop spectrophotometer (Thermo Scientific, USA). Afterwards, the $18 \mathrm{~S}$ rDNA region of the eukaryotic ribosomal operon was used in a DNA-microarray and for automated ribosomal intergenic spacer analysis (ARISA).

\subsubsection{DNA microarray}

The protocol for microarray analyses was identical to the one described in Wollschläger et al. (2014), however, other molecular probes were used. The cells targeted in the present investigation were different clades of cryptophytes and prasinophytes. An overview of the members of these clades and the corresponding probes is given in Table 3.

\subsubsection{ARISA}

For ARISA, a fragment of the internal transcribed spacer (ITS) region of the 18S rRNA gene was amplified via PCR using the forward primer 1528-6FAM (5'-ACTAGGAAGACGTCCAAGTGGATG-3') and the reverse primer ITS2 (5'-GCTGCGTTCTTCATCGATGC-3'). Per $25 \mu \mathrm{L}$ PCR reaction, approx. 20 ng DNA was used, and the whole analysis was carried out in triplicate. The PCR-protocol started with $94{ }^{\circ} \mathrm{C}$ for three min, followed by 34 cycles of $94{ }^{\circ} \mathrm{C}$ for $45 \mathrm{~s}, 55^{\circ} \mathrm{C}$ for $1 \mathrm{~min}$ and $72{ }^{\circ} \mathrm{C}$ for $3 \mathrm{~min}$. The reaction was kept at $72{ }^{\circ} \mathrm{C}$ for $10 \mathrm{~min}$ and cooled down to $4{ }^{\circ} \mathrm{C}$ at the end. Subsequently, in preparation of the analysis, $1 \mu \mathrm{L}$ of PCR solution was mixed with $15 \mu \mathrm{L}$ Hi-Di (Applied Biosystems, USA) and $0.3 \mu \mathrm{L}$ size-standard (GeneScan-500 ROX, Applied Biosystems, USA). The analysis of the PCR-products was carried out using an ABI 3130XL capillary sequencer (Applied Biosystems, USA), and data were evaluated using the GeneMapper 4.0 software (Applied Biosystems, USA). Fragment size patterns obtained were analyzed by non-metric multidimensional scaling.

\subsection{Data analysis}

Statistical, ecological and multivariate data analysis was performed using the freeware software package PAST (version 2.16, Hammer et al., 2001). Map plots were generated using the Ocean Data View Software (Schlitzer, 2012). For illustration purposes, data were interpolated between the measurement points (black dots) using the DIVA gridding feature of the software.

\section{Results}

\subsection{Abiotic parameters and chl-a distribution}

Generally, the eastern and - to a lesser degree - the southern regions of the German Bight were found to be influenced by freshwater input from the rivers Elbe, Weser, and Ems as well as by the coastal waters of the Wadden Sea. This was indicated by lower salinity, coupled with higher concentrations of CDOM and nutrients in these areas (SUP. 2). Nitrate levels were the highest in the earlier periods of the year (April, May, and June). For phosphate, very low values were detected in May 2010, while seasonal differences in the other cruises were much smaller. TSM concentrations were the highest in September in the shallow areas near the coast, probably because of strong wind-induced mixing resulting in increased re-suspension of mineral particles in the water 
Table 3

Molecular probes used in the course of this study with their respective target taxa.

\begin{tabular}{|c|c|c|c|}
\hline Target taxon & Probe sequence $\left(5^{\prime} \ldots 3^{\prime}\right)$ & Probe name & Reference \\
\hline All cryptophytes & ACGGCCCCAACTGTCCCT & Crypto B & Metfies and Medlin (2007) \\
\hline $\begin{array}{l}\text { Cryptophytes clade } 1 \\
\text { Cryptomonas }\end{array}$ & CATTACCCCAGTCCCATAACCAAGG & Crypt01-25 & Metfies and Medlin (2007) \\
\hline $\begin{array}{l}\text { Cryptophytes clade } 2 \\
\text { Rhinomonas } \\
\text { Rhodomonas }\end{array}$ & GCGTCCCACTACCCTACAGTTAAGT & Crypt02-25 & Metfies and Medlin (2007) \\
\hline $\begin{array}{l}\text { Cryptophytes clade } 3 \\
\text { Hanusia } \\
\text { Guillardia }\end{array}$ & GTGTTCCCGCGCACCACGGTTAAAT & Crypt03-25 & Metfies and Medlin (2007) \\
\hline $\begin{array}{l}\text { Cryptophytes clades } 4 \text { and } 6 \\
\text { Plagioselmis } \\
\text { Teleaulax } \\
\text { Geminigera } \\
\text { Komma } \\
\text { Chroomonas } \\
\text { Hemiselmis } \\
\text { Plagiomonas }\end{array}$ & CAAGGTCGGCTTTGCCTC & Crypt46 & Metfies and Medlin (2007) \\
\hline $\begin{array}{l}\text { Cryptophytes clade } 5 \\
\text { Proteomonas }\end{array}$ & TGCGTCCCAACGCCCCACAGTGAAG & Crypt053-25 & Metfies and Medlin (2007) \\
\hline $\begin{array}{l}\text { Prasinophytes clade } 1 \\
\text { Pterosperma cristatum }\end{array}$ & GGTTGCGTTAGTCTTGCT & Pras09A1 & Gescher et al. (2008) \\
\hline $\begin{array}{l}\text { Prasinophytes clade } 1 \\
\text { Pyramimonas spp. } \\
\text { Prasinopapilla spp. } \\
\text { Cymbomonas spp. }\end{array}$ & GCCGCCTTCGGGCGTTTT & Pras09A2 & Gescher et al. (2008) \\
\hline $\begin{array}{l}\text { Prasinophytes clade } 1 \\
\text { Halosphaera spp. }\end{array}$ & AACTGGCTCGGTACGCGG & Pras09D & Gescher et al. (2008) \\
\hline $\begin{array}{l}\text { Prasinophytes clade } 2 \\
\text { Mamiellales } \\
\text { (Except Dolichomastix) }\end{array}$ & CGTAAGCCCGCTTTGAAC & Pras04 & Not et al. (2004) \\
\hline $\begin{array}{l}\text { Prasinophytes clade } 3 \\
\quad \text { Nephroselmis pyriformis } \\
\text { Pseudoscoufieldia marina }\end{array}$ & TAAAAGACCGACCGCTTC & Pras10B & Gescher et al. (2008) \\
\hline $\begin{array}{l}\text { Prasinophytes clade } 3 \\
\quad \text { Nephroselmis pyriformis }\end{array}$ & CGTTTCAACTCGACCAGT & Pras10F & Gescher et al. (2008) \\
\hline $\begin{array}{l}\text { Prasinophytes clade } 3 \\
\text { Nephroselmis olivacea }\end{array}$ & CACTGGCGCGCCCCATCT & Pras10H & Gescher et al. (2008) \\
\hline $\begin{array}{l}\text { Prasinophytes clade } 5 \\
\text { Pseudoscoufieldia marina } \\
\text { Pycnococcus provasolii }\end{array}$ & ACGGTCCCGAAGGGTTGG & Pras01 & Not et al. (2004) \\
\hline $\begin{array}{l}\text { Prasinophytes clade } 5 \\
\text { Pseudoscoufieldia marina } \\
\text { Pycnococcus provasolii }\end{array}$ & CCGACAGAAAGACGCAGA & Pras07 & Not et al. (2004) \\
\hline $\begin{array}{l}\text { Prasinophytes clade } 6 \\
\text { Prasinococcales }\end{array}$ & GCCACCAGTGCACACCGG & Pras03 & Not et al. (2004) \\
\hline $\begin{array}{l}\text { Prasinophytes clade 7A } \\
\text { Unclassified sequences }\end{array}$ & GCCAGAACCACGTCCTCG & Pras05 & Not et al. (2004) \\
\hline $\begin{array}{l}\text { Prasinophytes clade 7B } \\
\text { Unclassified sequences }\end{array}$ & AATCAAGACGGAGCGCGT & Pras06 & Not et al. (2004) \\
\hline $\begin{array}{l}\text { Prasinophytes clade } 7 C \\
\text { Picocystis salinarum }\end{array}$ & ATTGTGTGGGTCTTCGGG & Pras08 & Gescher et al. (2008) \\
\hline
\end{tabular}

column. Chl- $a$ distribution (Fig. 1 ) was patchy and could not be directly linked to the measured nutrients (data not shown). However, chl- $a$ tended to be higher near the coast, although linear correlations between chl- $a$ and general coastal characteristics (using salinity as proxy) were weak (Table 4).

\subsection{Contribution of phytoplankton size classes to biomass}

\subsubsection{Microscopy and flow cytometry}

Carbon biomass was calculated for each of the three size classes separately on the basis of cell dimension measurements made by either microscopic observation (microphytoplankton) or flow cytometry (nano- and picophytoplankton). The values for the different size classes were summarized to estimate total biomass of the community for the respective stations (those of May 2010 were omitted due to the lack of microphytoplankton data), and correlated linearly with HPLCderived chl- $a$ concentrations $\left(\mathrm{R}^{2}=0.6, \mathrm{p}<0.001\right.$; Fig. 2$)$.
Averaged over all cruises, microphytoplankton constituted the major part of bulk autotrophic carbon biomass (61\%), with diatoms made up for 40 and dinophytes for $21 \%$, respectively (other classes were negligible). Nanophytoplankton contributed over all cruises with $38 \%$, while picophytoplankton contribution was almost negligible (below 2\%). For this reason, nano- and picophytoplankton were summarized in the following as ultraplankton ( $<20 \mu \mathrm{m}$, Fogg, 1991).

Considering the cruises separately, an often high average contribution of ultraphytoplankton to total carbon biomass was visible (Fig. 3A). In some cases, it equaled or even exceeded that of microphytoplankton (September 2010, April and June 2011). High contributions of small phytoplankton in spring and early summer are in accordance with observations made by Knefelkamp (2009) in the waters around Helgoland. On a spatial scale, contribution of ultraphytoplankton was patchy, but not completely randomly distributed (Fig. 4, left panels). As a tendency, higher proportions could be observed at the most offshore areas but occasionally also 


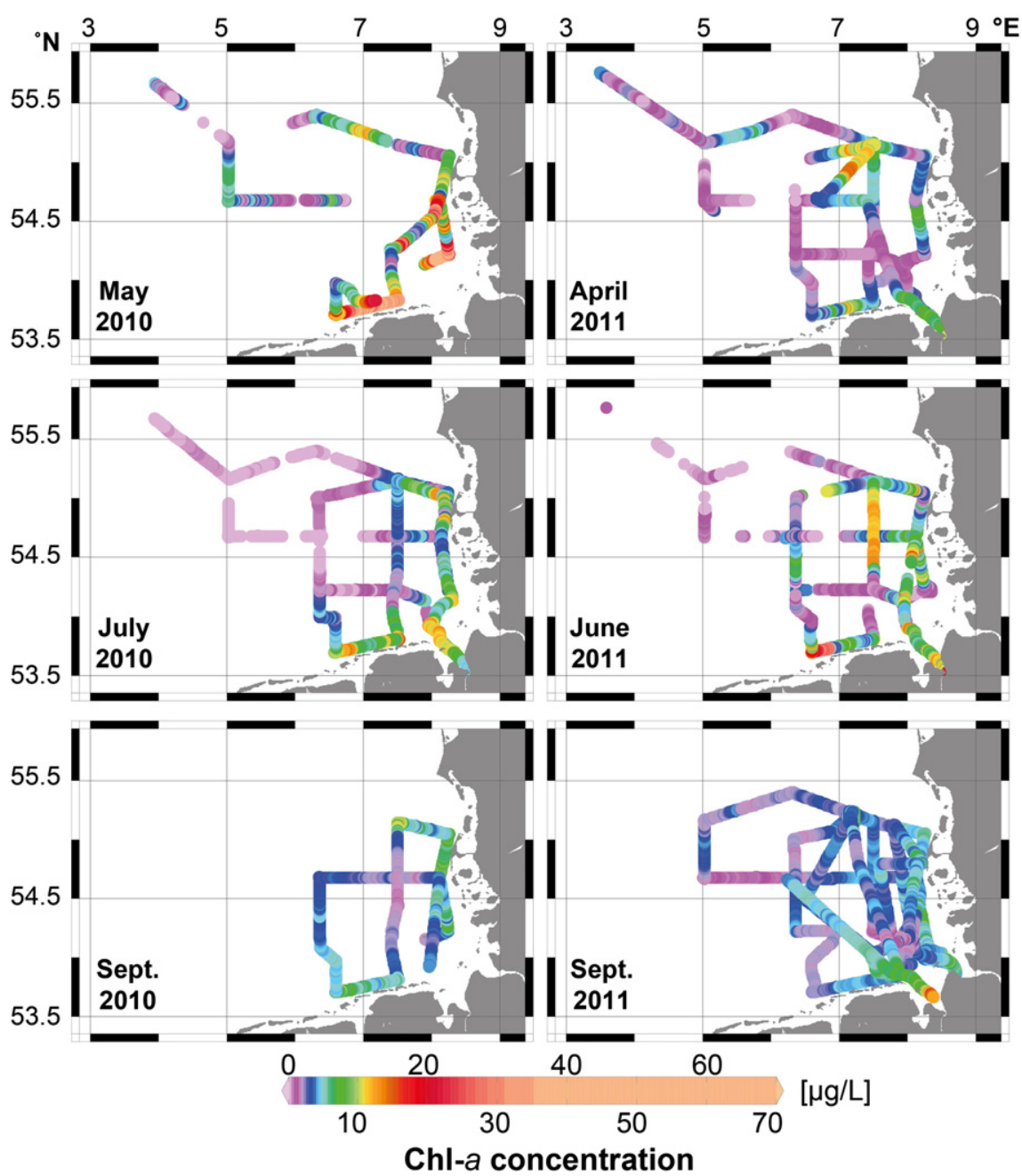

Fig. 1. Map plots of continuously measured fluorescence-based chl- $a$ concentrations. The color scaling of the figure is non-linear to present differences more clearly.

close to the coast, especially near the southwestern and eastern parts of the German Bight.

\subsubsection{Pigment data}

To estimate also the contribution of the different phytoplanktonrespectively size classes to total chl- $a$, based on the measured accessory pigment concentrations, the CHEMTAX-approach (Mackey et al., 1996) was used. According to these results, again groups were dominating which are commonly considered to be of microphytoplankton size (diatoms and dinoflagellates, contribution averaged over all cruises approx. 75\%). However, the majority of the microphytoplankton was assumed to be diatoms (Fig. 3B). The groups which can be associated with the ultraphytoplankton (prasinophytes, cryptophytes, and prymnesiophytes) showed higher proportions in summer. Similar to the microscopy/flow cytometry dataset, the contribution of the

Table 4

Linear regressions between chl- $a$ concentration and salinity. With exception of June 2011, $\mathrm{p}<0.05$ in all cases.

\begin{tabular}{lllrlll}
\hline Cruise & Slope & Slope error & Offset & Offset error & $\mathrm{R}^{2}$ & $\mathrm{n}$ \\
\hline May 2010 & -3.38 & 0.09 & 120.99 & 2.96 & 0.42 & 1897 \\
July 2010 & -1.3 & 0.02 & 44.98 & 0.68 & 0.36 & 6899 \\
September 2010 & -0.57 & 0.02 & 21.92 & 0.76 & 0.15 & 3362 \\
April 2011 & -0.42 & 0.02 & 16.41 & 0.5 & 0.08 & 9049 \\
June 2011 & -0.06 & 0.03 & 5.49 & 1.05 & 0 & 5941 \\
September 2011 & -0.4 & 0.01 & 16.39 & 0.21 & 0.19 & 16,202 \\
\hline
\end{tabular}

smaller size classes was especially high in the more offshore areas (Fig. 4, right panels). Likewise high contributions of ultraphytoplankton near the coast as visible for carbon estimates were not observed in the pigment-based data.

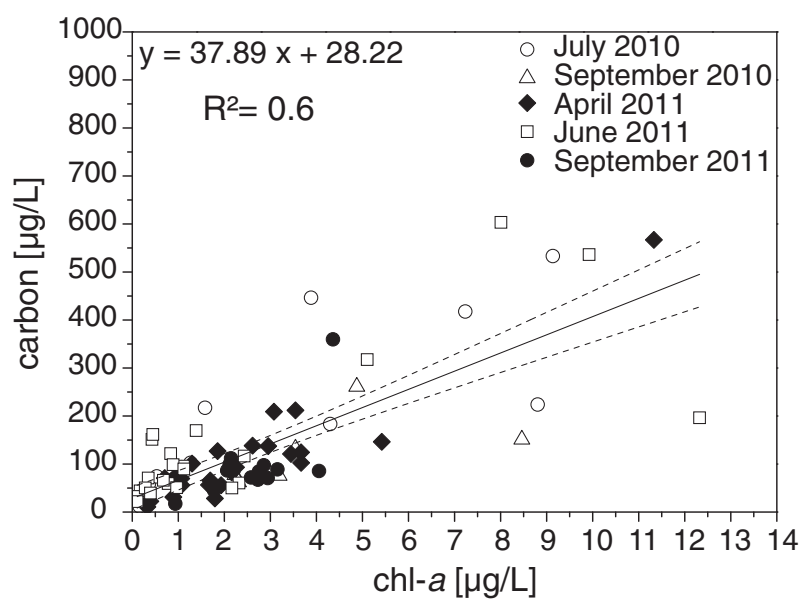

Fig. 2. Correlation between HPLC measured chl- $a$ concentrations and corresponding calculated total carbon based on cell size measurements by microscopy and flow cytometry. The dotted lines represent the $95 \%$ confidence interval of the linear fit. Both slope and offset are different from zero at $\mathrm{p}=0.05$. 

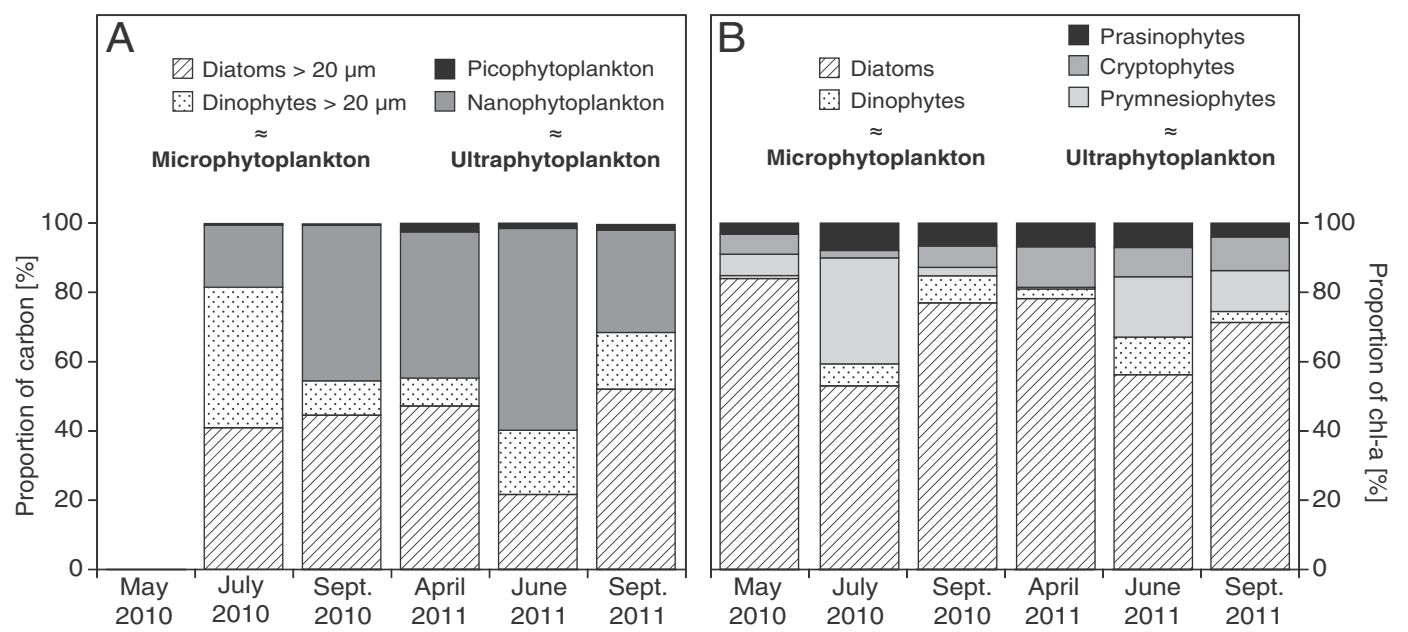

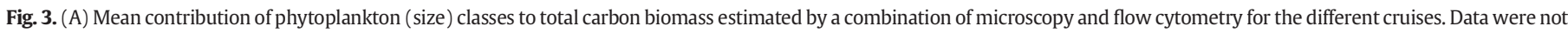
available for May 2010. (B) Mean contribution of phytoplankton classes to total chl- $a$ biomass based on CHEMTAX pigment data analysis.

\subsection{General community patterns}

The phytoplankton communities at the cruise stations were investigated as a whole by obtaining their genetic "fingerprints" via automated ribosomal intergenic spacer analysis (ARISA). The resulting data were analyzed by non-metric multidimensional scaling, and three distinct groups could be distinguished (Fig. 5A): The first group included all stations from 2010, with no clear differences between the seasons, while the second group was a tight cluster consisting of the stations of April and June 2011. Isolated from both groups was the September cruise 2011. In order to test whether environmental factors had an influence on the observed distribution, non-metric multidimensional scaling was also performed on environmental data available for the stations. In contrast to the ARISA data, the resulting pattern showed some seasonality (Fig. 5B): Spring cruises of both years formed one group, while the other cruises formed a second. Apparently, there was no relation between the distribution of the stations according to the ARISA data and the distribution according to the environmental parameters. This was also confirmed by a Mantel test between both similarity matrices $(\mathrm{R}=-0.11, \mathrm{p}=0.974)$.

\subsection{Taxonomical composition}

\subsubsection{Microscopic observations}

Microscopic analysis targeted the microphytoplankton fraction and its biodiversity, since members of this size class are readily countable and identifiable by this method. Species accumulation curves (SUP. 4) proved that the number of samples investigated for the different cruises ( $\mathrm{n}=15-25$ ) was sufficient to cover the majority of taxa present in the study area, since they almost reached saturation. Furthermore, they suggested the highest numbers of taxa in autumn, the smallest numbers in summer, and an intermediate value in spring. These seasonal differences in microphytoplankton biodiversity were confirmed by the average values of the Simpson index '1-D' calculated for the different cruises. It is a robust measurement of biodiversity (Magurran, 2004) and more meaningful than the simple number of taxa, because it also takes the abundance per taxon into account. The Simpson index ranges from 0 to 1 , with increasing values to more 'even' or diverse communities with several equally contributing taxa. Its averaged value over all respective cruise stations was 0.52 in July 2010, 0.63 in June 2011, and 0.67 in April 2011. In both years, the September cruises showed statistically significant higher values with 0.8 in 2010 and 0.85 in 2011 $(\mathrm{p}<0.05$ according to an ANOVA), indicating a more diverse community than in the other seasons. Seasonal differences were also found with respect to the spatial variability of community composition, which can be expressed as beta-diversity (Whittaker, 1960). Calculated from taxa presence/absence, beta diversity (and therefore spatial heterogeneity of the communities) was higher in summer (3.29 in July 2010 and 3.52 in June 2011), than in spring (2.87 in April 2011), while it was the lowest in September of both years (1.13 in 2010 and 1.4 in 2011).

According to taxonomical classification and cell counts, no blooms of particular species were observed during the cruises. The dominant groups were diatoms and dinoflagellates, other groups played only a marginal role. In Fig. 6, the percentage of dinoflagellates on total microphytoplankton population is displayed in terms of cell number, carbon and chl- $a$. It can be seen that dinoflagellates dominated the community in the more offshore areas, especially in summer, while diatoms dominated the coastal areas. For analyzing the community compositions in more detail, a canonical correspondence analysis (CCA) was performed (Fig. 7). For clarity reasons, only those taxa were included which constituted $90 \%$ of total dinoflagellate abundance or $80 \%$ of non-dinoflagellate abundance of a specific cruise. Temperature, salinity, CDOM and turbidity were used as explanatory environmental variables. With respect to the arrangement of the arrows representing the environmental parameters, the ordination plot can be separated roughly into four sections: Warm/clear, warm/turbid, cold/clear, and cold/turbid environments. The positions of the different taxa in relation to the environmental variables were used to draw conclusions about their preferred occurrence. Considering the distribution of the stations, the CCA showed a separation between spring, summer and autumn communities. However, diatom taxa were present all through the year and were therefore found in all environments. Especially the genus Chaetoceros was an important element of the diatom community with various members. Most of them appeared to occur in clearer waters, only Chaetoceros pseudocurvisetus was found in more turbid regions, as well as Eucampia zodiacus and the majority of the pennate forms (e.g., Navicula spp., Bacillaria paxillifer, Pseudo-nitzschia seriata). Mediopyxis helysia, a species newly recorded in the German Bight (Kraberg et al., 2012), was also found in the course of this study. In contrast to the ubiquity of the diatom taxa, most dinoflagellate taxa were located in the upper right section of the graph, indicating an association with warmer, clearer waters characteristically for the summer periods. Besides small thecate and athecate dinoflagellates, Dinophysis acuminata was frequently found as well as several members of the genus Ceratium.

\subsubsection{Flow cytometry}

Gaining taxonomical information about the ultraphytoplankton community via flow cytometry is limited. However, despite having the 


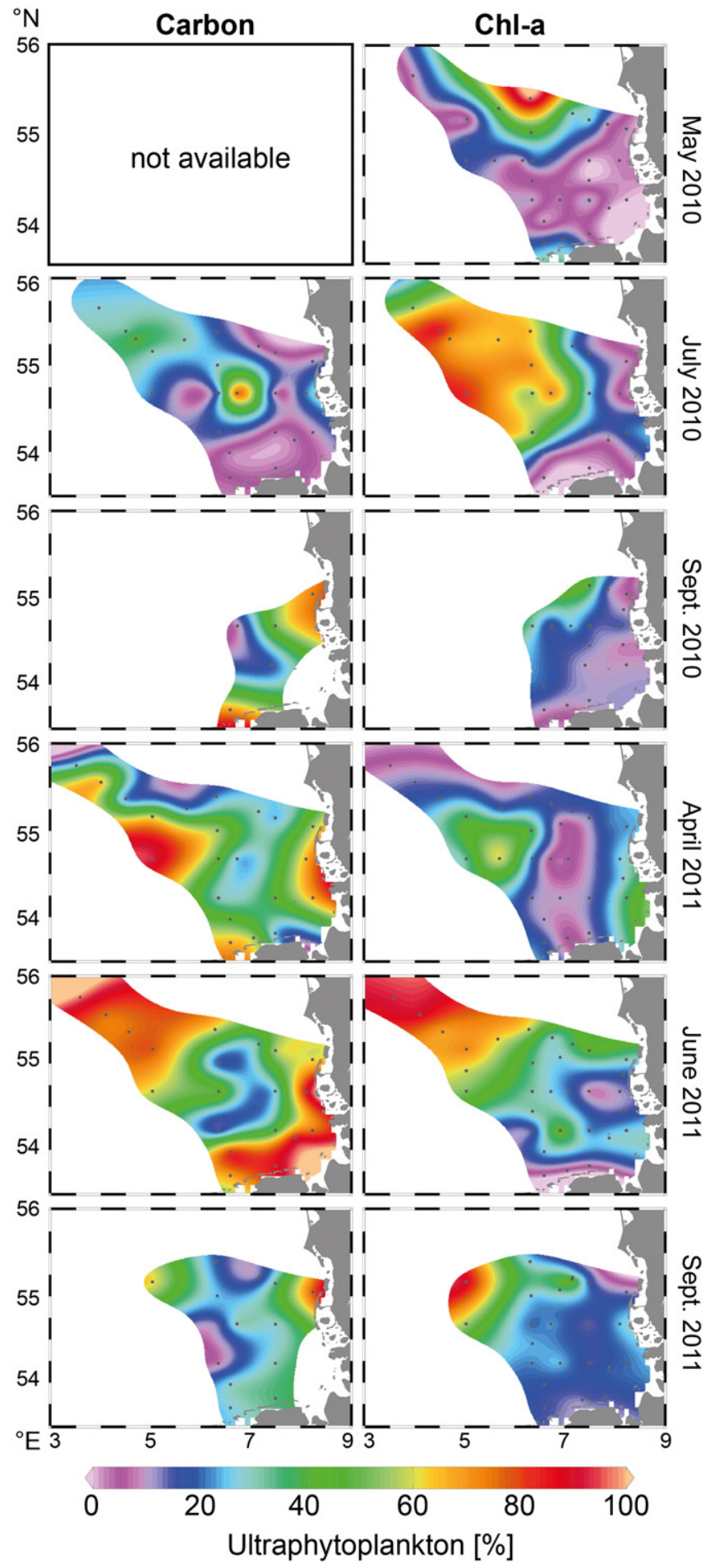

Fig. 4. Spatial distribution of ultraphytoplankton contribution to biomass on the different cruises. Left panel shows the values estimated from microscopic and flow cytometry observation, the right panel those based on pigment data.

possibility of differentiation between nano- and picophytoplankton, also the presence of cryptophytes can be detected by measuring the orange fluorescence originating from phycoerythrin (Li and Dickie, 2001). Thus, the ratio of orange to red chl- $a$ fluorescence was used in this study to estimate the proportion of cryptophytes in the ultraphytoplankton (Fig. 8). Cyanobacteria, which also show orange fluorescence, were omitted from the analysis on the basis of their smaller size (and therefore lower side-scatter). Although being a relatively crude parameter due to the variability inherent in fluorescence measurements
(Falkowski and Kiefer, 1985), this ratio allows the detection of differences between samples. The variation in the ratio could not be linked to variations in environmental parameters between cruise stations (data not shown). On a temporal scale, however, it indicated a relatively constant proportion of cryptophytes in all seasons of 2010. In 2011, more cryptophytes were present in April and June, while in September, the proportion of cryptophytes decreased again.

\subsubsection{Pigment data}

According to the CHEMTAX-analysis, in all seasons the majority of chl- $a$ biomass was made up by diatoms (Fig. 3B). The contribution of dinoflagellates was much lower compared to the estimations made by the microscopic/flow cytometry approach (Fig. 3A), and also their dominance in the offshore regions was not visible (Fig. 6A). An apparent increase of prymnesiophytes was observed during the summer of both years, to a large degree responsible for the increased contribution of ultraphytoplankton to total chl- $a$ biomass in these months (see Section 3.2). In contrast, prasinophyte contribution was relatively constant over all cruises. The proportion of cryptophytes in 2010 was higher in spring and autumn compared to summer of the same year, but were in general lower than in 2011. Thus, the development of this group was to a certain degree similar to the results obtained by the flow cytometric fluorescence data.

\subsubsection{Microarray results}

The DNA-microarray targeted different clades of cryptophytes and prasinophytes because both classes have been shown to be important contributors to the small phytoplankton in the German Bight (Gescher et al., 2008; Metfies et al., 2010). Since the obtained signal intensity of a DNA-microarray can be biased from several sources (Medlin et al., 2006; Wollschläger et al., 2014), the data were only interpreted with respect to the presence or absence of the different clades in this study.

The left panel of Fig. 9A shows the relative abundance of signals obtained for the various clades of cryptophytes on the different cruises. It can be seen that the probe specific for the whole class gave a signal at nearly all stations. The single clades showed similar presences in 2010 (only clades 4, 5 and 6 were less frequent in July) while at the beginning of 2011 the presence of all clades was considerably lower. However, to the end of the year, the values increased again, but most clades were much less present than in 2010. A similar development was also visible in the prasinophyte community (Fig. 9A, right panel): Clades were present at a high percentage of stations in 2010 cruises (with a drop of some clades in July) while in 2011, the presence of all clades was much lower but with a tendency to increase towards September.

Using the number of signal-giving probes per station as an index for cryptophyte and prasinophyte biodiversity, the results showed a high accordance of cryptophyte and prasinophyte diversity distribution (Fig. 9B). It was patchy, and direct correlations with environmental parameters, biomass distributions, or microphytoplankton diversity were not found (data not shown). However, some tendencies could be deduced from the figure: On the majority of the cruises, high diversity occurred in the southern German Bight in the region of the East Frisian

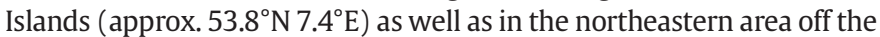
coast of Sylt $\left(54.9^{\circ} \mathrm{N} 8.3^{\circ} \mathrm{E}\right)$. In contrast, a lower diversity was frequently observed at the Elbe estuary $\left(53.9^{\circ} \mathrm{N} 8.7^{\circ} \mathrm{E}\right)$, and in the inner parts of the German Bight.

\section{Discussion}

We used an complementary approach based on light microscopy, HPLC-based phytoplankton pigment determination, in situ chlorophyll- $a$ fluorescence measurements, flow cytometry, molecular fingerprinting and DNA microarray analyses to assess spatial and temporal variability in phytoplankton community in the German Bight, including all three phytoplankton size classes as far as possible. With exception of microscopy and HPLC, focus laid on methods which are relatively low in effort 

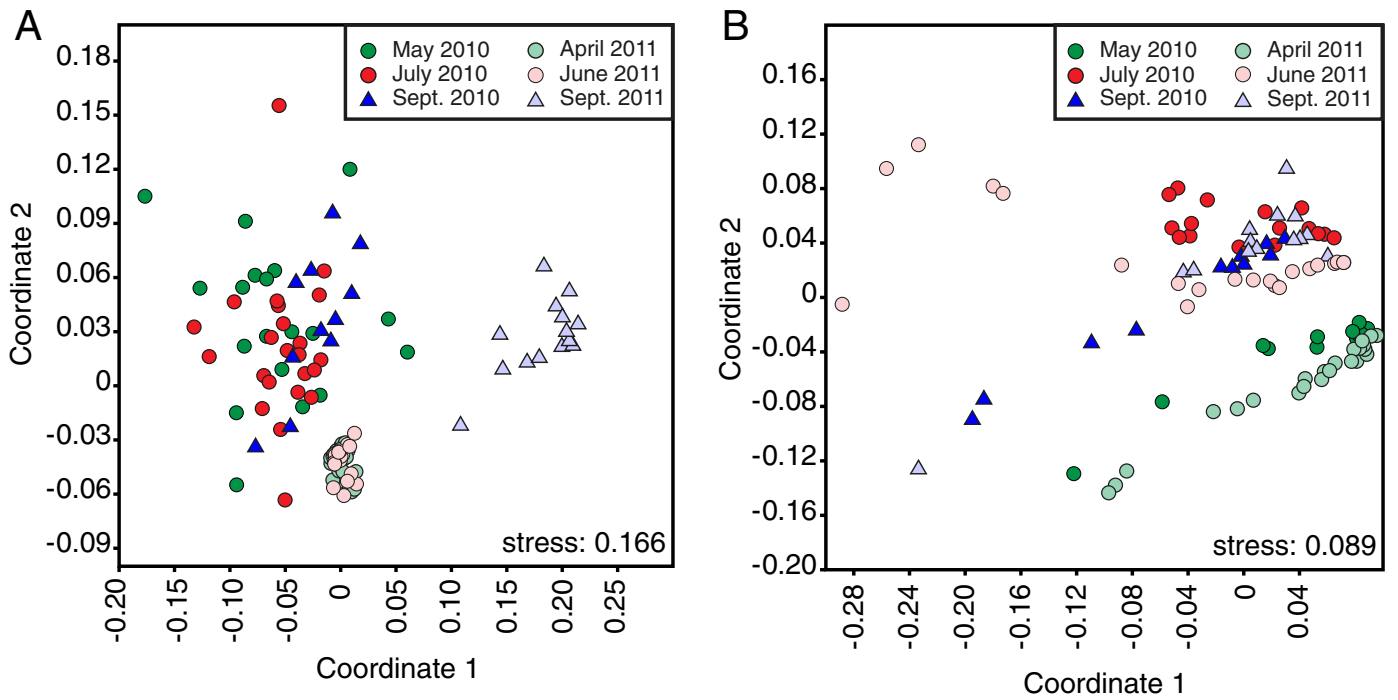

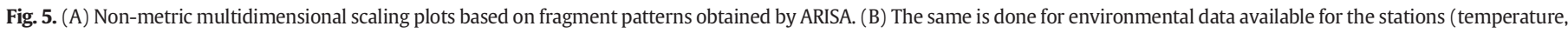
salinity, CDOM, and turbidity).

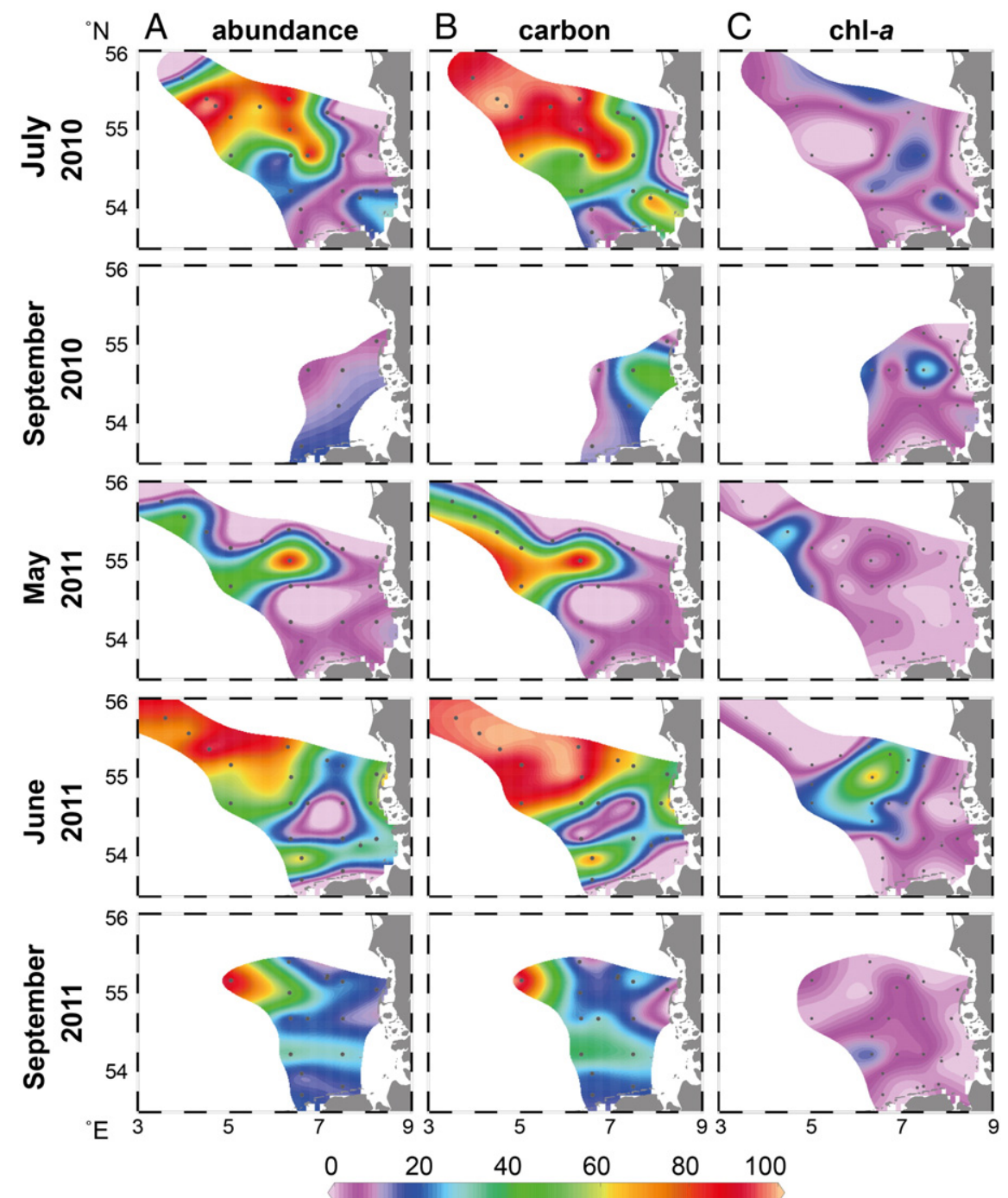

Dinoflagellates [\%]

Fig. 6. Distribution of dinoflagellates in terms of (A) cell numbers, (B) carbon, and (C) chl- $a$ (estimated by CHEMTAX). 


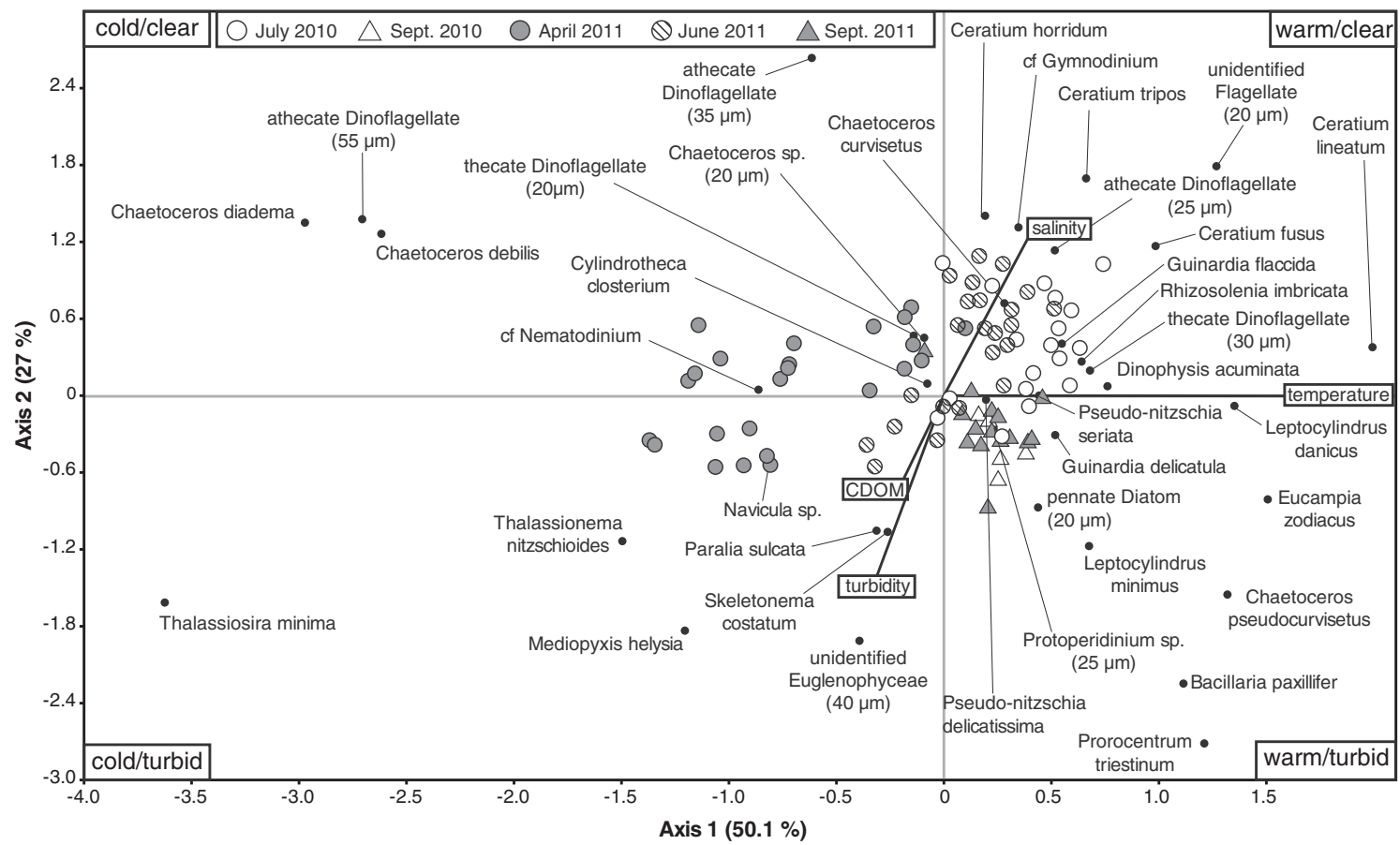

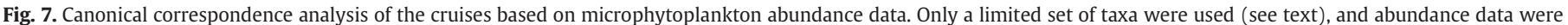

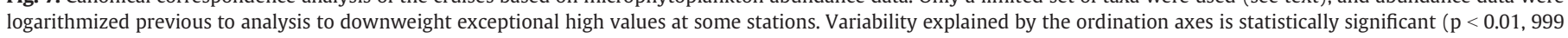
permutations).

and allow therefore a high sample throughput. The fluorescence measurements give estimates of chl- $a$ distribution in high resolution, while flow cytometry has been shown to allow a fast and accurate counting of small phytoplankton cells in a sample (Olson et al., 1985; Phinney and Cucci, 1989; Vives-Rego et al., 2000). Molecular biological approaches (for an overview of common methods see De Bruin et al., 2003) are useful for obtaining taxonomic information on small and hardly identifiable cells. Fingerprinting techniques provide information on general changes in the phytoplankton community (Knefelkamp, 2009; Wolf et al., 2013), although they are not suitable for an absolute assessment of biodiversity (Bent et al., 2007). The ARISA (automated

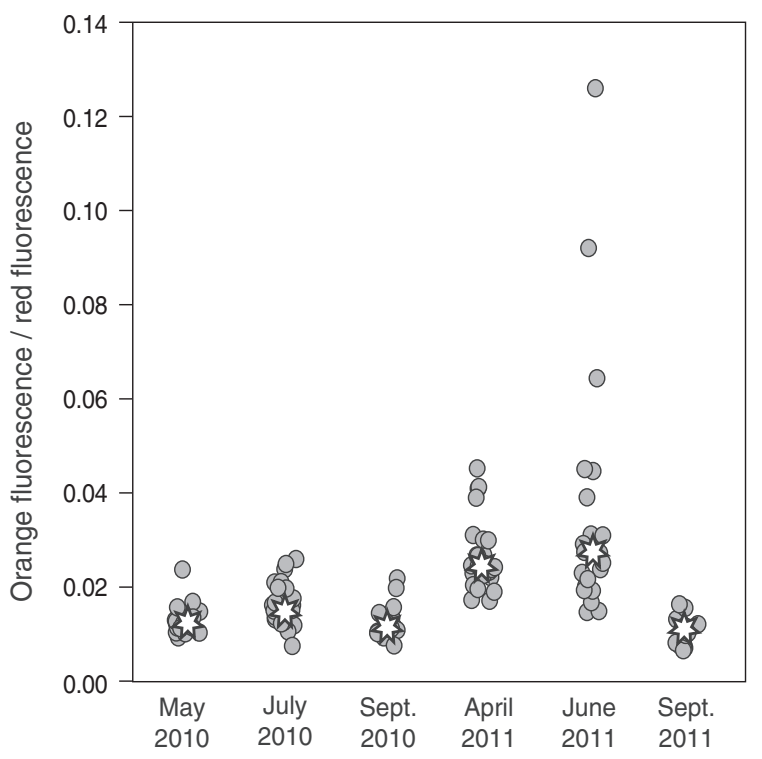

Fig. 8. Ratio of orange to red fluorescence measured for the ultraphytoplankton fraction on the stations of the different cruises. The stars mark the median value of the respective cruise. ribosomal intergenic spacer analysis) approach used in this study has been often applied for prokaryotic communities (e.g., Danovaro et al., 2006; Kovacs et al., 2010), but has also been used for eukaryotes (Fechner et al., 2010; Wolf et al., 2013). In contrast, DNA-microarrays can provide taxon-specific information about the phytoplankton community in a sample (Kochzius et al., 2007; Metfies and Medlin, 2005). These data are commonly based on the detection of sequences in the 18S-rRNA gene in the ribosomal operon by taxon-specific, complementary oligonucleotide molecular probes. This particular gene allows investigations on different taxonomical levels (Díez et al., 2001; Moon-van der Staay et al., 2001). Microarrays have frequently been used for analyzing prokaryotic communities of various origins (Nelson et al., 2011; Sessitsch et al., 2006), but also for cryptophytes and prasinophytes in the German Bight (Gescher et al., 2008; Metfies et al., 2010).

\subsection{Biomass distribution and contribution of size classes}

Phytoplankton biomass is certainly one of the most important and most requested parameters in biological oceanography and conveniently estimated by in situ chl- $a$ fluorescence measurements. Such measurements are suitable for illustrating general patterns of phytoplankton distribution (patchiness) in high resolution (Fig. 1). However, their interpretation as proxy for phytoplankton biomass requires some caution due to the variability of both the fluorescence/chl- $a$ and the chl- $a$ /(carbon)biomass relationship (Banse, 1977; Falkowski and Kiefer, 1985; Geider, 1987; Hallegraeff, 1977; Jiménez et al., 1987; Llewellyn and Gibb, 2000). Naturally, also the estimations of carbon biomass itself by optical means can be biased by several factors, in case of microscopy by the accuracy of cell counts, the cell size measurements, or the equations used for biovolume and carbon calculation. For flow cytometry, uncertainties arise from the fact that size estimation is generally based on light scattering measurements, which depends on the orientation of the cell during measurement, and which is of course different between the spherical beads used for calibration and phytoplankton cells, which normally have other shapes and in general a different 

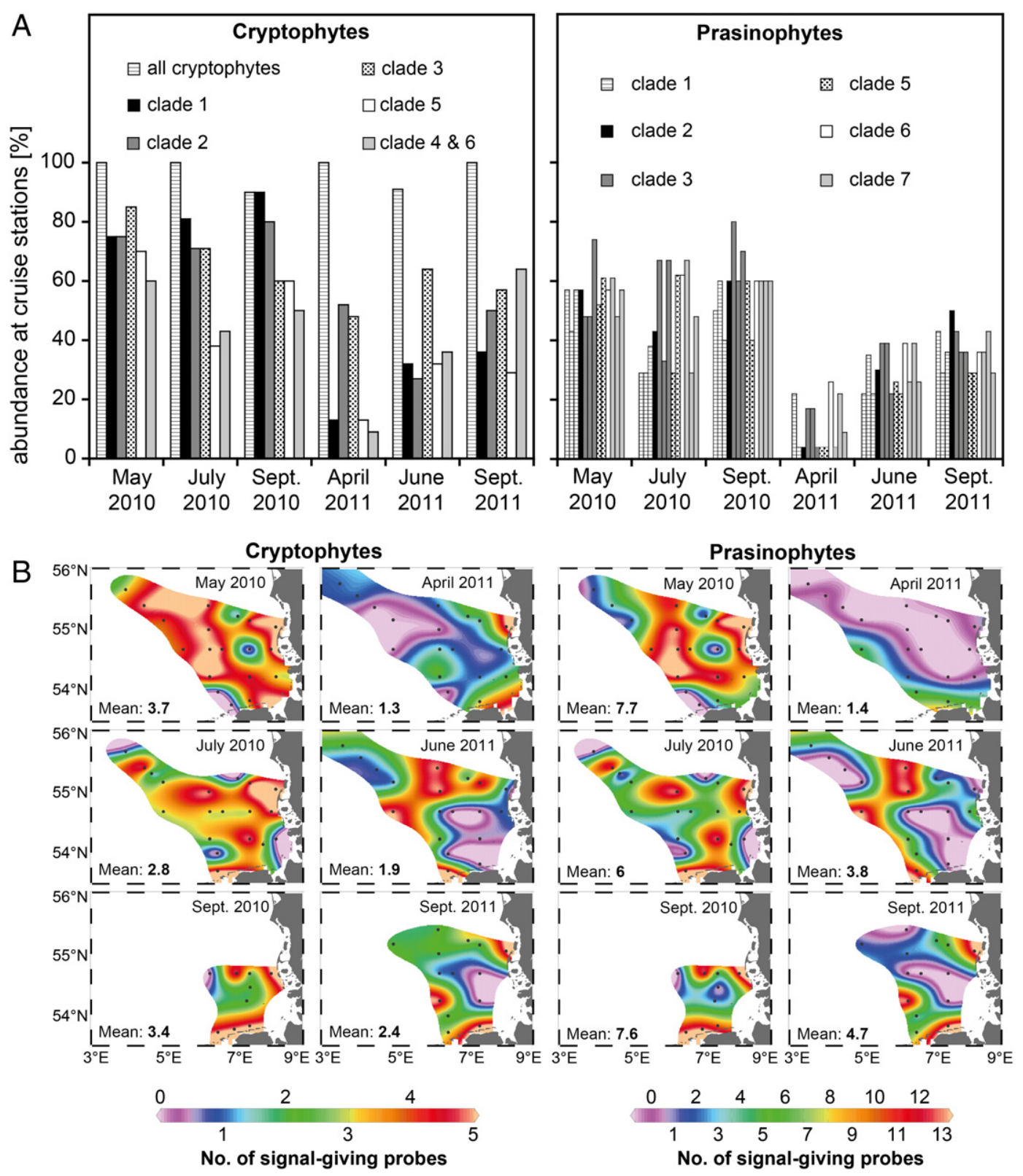

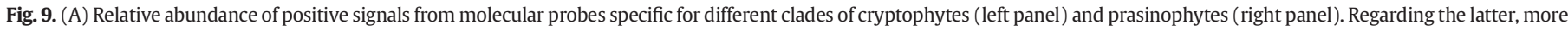

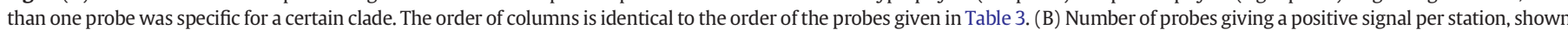
for the different cruises.

structure. Additionally, the use of average size values for the respective cruise station introduced additional uncertainties.

However, these potential biases should be small enough not to interfere with the main conclusions drawn from the data. The plausibility of the overall biomass estimations is indicated by the slope between chl- $a$ and estimated total carbon biomass (Fig. 2), which lies with a value of approx. 38 in the range between 20 and 50 found for healthy cells of diatoms, dinoflagellates, and microflagellates in the North Sea (Reid et al., 1990).

The impossibility of explaining the observed biomass distribution by the measured CDOM or nutrient concentrations can be caused by different reasons: Phytoplankton itself has an influence on nutrient distribution due to the uptake and release of nutrients, and although higher loads of nutrients as occurring in coastal waters (Radach, 1992), as well as humic organic substances can promote phytoplankton growth (Carlsson and Granéli, 1993; Prakash and Rashid, 1968), its growth exhibits also a time-lag in the response to changing nutrient conditions.
Internal reservoirs allow cell growth also under low ambient nutrient conditions (Dortch, 1982) while on the other hand incorporated nutrients have to be assimilated into organic molecules before they can be used for growth processes (Wheeler, 1983). Also an imbalance or lack of certain nutrients can limit phytoplankton growth (Tilman et al., 1982), as in the case of silicon, which is required for diatom frustule formation. Thus, interpretation of biomass distribution by nutrient situation can be difficult when only a snapshot of the situation is available like it is the case on research cruises. This needs time series data where the development of both parameters can be tracked over a longer period, or modeling approaches (e.g., Baretta et al., 1995). Of course, also other parameters like light availability (Loebl et al., 2009), zooplankton grazing (e.g., Calbet and Landry, 2004), or degradation by viruses (Brussaard, 2004; Rhodes et al., 2008) influence phytoplankton biomass development and have to be taken into account.

The different results regarding the contribution of the size classes to total biomass (Fig. 3 and 4) are explainable by the different 
methodological approaches. One is based on optically derived carbon biomass estimates, while the other relies on pigment estimates. Both parameters describe phytoplankton biomass differently and are not necessarily interchangeable (see also Fig. 2). Microphytoplankton contribution is probably overestimated by the pigment-based approach at the expense of the other size classes, since its calculation is based on the assumption that diatoms and dinoflagellates respectively their marker pigments fucoxanthin and peridinin are only present in this size class. But both classes can have also smaller representatives (Gao et al., 2003; Moon-van der Staay et al., 2001) and in turn, some pigments associated with smaller phytoplankton can also occur in microphytoplankton species. Thus, the pigment based estimation of size class contribution has some uncertainties due to the impossibility to assign certain marker pigments to a certain size class. For this reason, at least regarding the ultraphytoplankton distribution the flow cytometry approach might reflect the true situation better, inasmuch as it allows also the detection of small cells not carrying marker pigments. Nevertheless, on a spatial scale, both approaches show a similar picture, and even by looking at the differences more information can be gained: The differences between both methods in detecting the ultraphytoplankton were especially high in the coastal areas (Fig. 4), indicating that in these regions this size class consisted to a considerable amount of diatoms and dinoflagellates.

Both flow cytometry and pigment analysis agreed with a higher contribution of small cells to biomass in the more offshore, nutrient poor regions. This is in accordance with observations made by Agawin et al. (2000) and Sabetta et al. (2008), and can be explained by the competitive advantage of smaller cells under low nutrient conditions (Chisholm, 1992; Fogg, 1991). They have a higher surface/volume ratio which enhances the utilization of available nutrients. This ratio is lower for larger cells, which are in addition more affected by sinking and were therefore successively removed from the community when nutrient levels decline. However, the flow cytometry approach indicated also frequently high contributions of small phytoplankton in coastnear areas of the German Bight. This was also observed by Hesse et al. (1989), which attributed it primarily to frontal zone effects due to tidal mixing or river plumes. But coastal waters are also often quite turbid that can limit the availability of light (see SUP. 1 for distributions of TSM, and also CDOM). Since small cells are also more efficient in light absorption than the larger ones due to a lower pigment packaging effect (Kirk, 1994; Morel and Bricaud, 1981), they might have also a certain competitive advantage under low light conditions. That could be an explanation for their stronger presence in certain coastal areas. Of course, additional factors which have not been assessed in this study, like selective grazing by zooplankton can also shape the phytoplankton size class distribution (Gaul and Antia, 2001; Lindén and Kuosa, 2004; Riegman et al., 1993).

\subsection{Taxonomic composition}

When looking at the taxonomic composition of the phytoplankton, the ARISA fingerprint (Fig. 5A) suggested differences in the community between 2010, the first half of 2011, and the end of 2011. Similar differences were not observed in the microscopy-based microphytoplankton data, instead, the values for Simpson-index, for beta-diversity, and the position of stations in the CCA (same seasons of both years close to each other; Fig. 7) indicated seasonal behavior of the community. Minor variations between 2010 and 2011, as observable for the summer stations, are probably related to differences in phytoplankton seasonal succession. The higher occurrence of dinoflagellates in summer of both years is in accordance with results published by e.g., Hagmeier and Bauerfeind (1990), Peeters and Peperzak (1990) and Hickel (1998). Under stratified, oligotrophic conditions they have competitive advantages over diatoms (Fogg, 1991) because they require no silicon for cell wall formation and are able to exploit nutrient rich water near or below the thermocline due to diurnal migrations (Cullen, 1985; MacIntyre et al., 1997). Especially the genus Ceratium was frequently abundant and has contributed to biomass, which is a typical feature of the North Sea in the second half of the year (Reid et al., 1990, see also various datasets of the Helgoland Roads time series at www.pangaea.de).

Seasonality with a lower contribution of diatoms in summer was also seen in the pigment-based class estimations. However, dinoflagellate contribution in this season was underestimated compared to the microscopic data, in favor of an increased contribution of prymnesiophytes. Partially, this could be explained by the high pigment diversity within the dinoflagellates due to acquisition of different types of chloroplasts by multiple endosymbiotic events (Zapata et al., 2012). This might limit the validity of the initial pigment ratios assumed for dinoflagellates in the CHEMTAX analysis and weaken its ability to estimate this group correctly. Furthermore, the chl- $a$ and also other pigment concentrations were quite low in the offshore regions (where the majority of the dinoflagellates was present according to microscopy). That could have also introduced a bias in the pigment analysis.

Regarding the results for the ultraphytoplankton, the molecular probe specific for all cryptophytes indicated an ubiquitous presence of this group in the German Bight through the year. That is in accordance with results from Metfies et al. (2010) and is also supported by the flow cytometry and pigment data. Cryptophyte and prasinophyte diversity was spatially variable, but although not always harboring the highest biodiversity, turbid coastal areas regularly showed high diversities on all cruises. Since in these regions the ultraphytoplankton exhibited often also high carbon biomass proportions (compare Fig. 4), they appear to provide generally a suitable environment for small phytoplankton.

A response of the small phytoplankton community to seasonal changes of the environmental parameters similar to the microphytoplankton was not observed, with exception for the prymnesiophytes in the CHEMTAX-analysis. In contrast, a rather sharp change in the community between 2010 and 2011 was indicated by an increased cryptophyte contribution to biomass as well as a lower diversity in the cryptophytes and prasinophytes (Figs. 3B and 8). In September 2011, the community appeared to change again to some extent. Such a difference in the behavior of larger and smaller phytoplankton to seasonal changes of environmental parameters has been also observed by Not et al. (2007) for picophytoplankton. However, these changes generally matched the pattern of the ARISA. Interestingly, the fingerprint reflected the changes in the small phytoplankton, but not the seasonality of the microphytoplankton. This indicates a large impact of the small phytoplankton community on this method, which can be explained by its high biodiversity (especially of picophytoplankton) in marine ecosystems (Knefelkamp, 2009; Moon-van der Staay et al., 2001; Not et al., 2007; Vaulot et al., 2008). Furthermore, fingerprinting methods tend to neglect rare species (Liu et al., 1997), and in terms of cell numbers, the ultraphytoplankton was approx. $100 \times$ more abundant than the microphytoplankton (data not shown). Thus, the signal obtained from the microphytoplankton was probably masked by the one obtained from the nano- and picophytoplankton. For this reason, samples should be size-fractionated by filtering in advance for a more accurate analysis of the different size classes by fingerprinting methods like the ARISA.

\section{Conclusions}

Patterns found in this study like the occurrence of higher biomass near the coast, or the increased contribution of dinoflagellates (e.g., Ceratium) especially in summer agreed well with older observations. They appear to be stable features largely untouched by climate change effects like the temperature increase of about $1.1{ }^{\circ} \mathrm{C}$ in the German Bight over the last 45 years (Wiltshire and Manly, 2004). Furthermore, the results of this study indicated a behavior or development of the ultraphytoplankton community which is different from those of the microphytoplankton community. This finding emphasizes both the value but also the requirement of using other methods in addition to 
routinely microscopic observation. While the microphytoplankton followed a well-known succession according to seasonal changes in environmental parameters, the factors governing the changes in distribution and diversity of the small phytoplankton remain largely unknown. This makes the interpretation of the observed patterns difficult, and qualitative and quantitative taxonomical data for comparison are scarce. To close this knowledge gap, the database regarding the ultraphytoplankton in the German Bight has to be broadened. This is of particular importance with respect to the nanophytoplankton which contribution in terms of biomass is most likely underestimated by pigment analysis or light microscopy alone. Since variability in the phytoplankton community can be high, a comprehensive analysis of phytoplankton community in the German Bight requires high frequency measurements over a larger area to cover variability both in time and space. In turn, this requires the use of methods relatively low in effort, like optical and molecular biological approaches. The complementary use of in situ measurements, microscopy, flow cytometry, DNAmicroarray, and ARISA in addition to microscopy and pigment analyses as used in this study can be seen as a first attempt in this direction, because it has shown to provide useful taxonomical and quantitative information on different levels of detail. Furthermore, the chosen methods have the advantage of being well suited for routine usage, what might be not yet the case for more sophisticated approaches. Thus, they can also be considered as being suitable to build up longterm datasets in complement to microscopic observations. This complementary use of different methods in time series would also provide means to identify breaks due to changes in the responsible investigator or the used equipment, which can bias in microscopic datasets. (Peperzak, 2010; Wiltshire and Dürselen, 2004).

For future investigations, of course not all the methods used in the present study are necessary to achieve an overview about the phytoplankton community. The final choice should depend on the particular scientific question. For detailed taxonomic investigation, microscopy is still the method of choice, but since its usefulness declines with cell size, molecular methods targeting single taxa (like microarrays) are of great advance. However, the use of microarrays requires the preselection of taxa, so it should be complemented with a fingerprint method like the ARISA applied on size-fractionated samples to see changes in the general community. A disadvantage of (DNA-based) microarrays is furthermore the limited quantitative information (see Wollschläger et al., 2014 for a more detailed discussion of this method). But since technology advances rapidly, especially in the molecular field, maybe other approaches which are currently relatively sophisticated and expensive (e.g., pyrosequencing) might be an alternative in the future. Flow cytometry or other forms of automated phytoplankton counting can in general be considered as very useful due to their ability to provide a rapid overview over the size distribution within the community and their potential for automation. For some applications, these methods might even replace microscopy. Pigment-based approaches like CHEMTAX provide comprehensive information about the community structure on class level; however, the accuracy of the information depends on the availability of pigment ratios for the classes present in the investigated region. A major drawback is the limited potential of this method to be automated and the resulting low spatiotemporal resolution. Maybe similar methods not relying directly on pigments, but on absorption or fluorescence spectra might be more useful for routinely usage.

However, to go the step from a proper description of phytoplankton dynamics to a real explanation, it is of course necessary to measure also its antagonists like zooplankton and viruses in comparable detail. Also here, an integrative approach of several methods, including especially molecular and automatic counting techniques, would be of great advantage. Only if these data are available, the assemblage can finally be modeled and the results validated by the observations.

Supplementary data to this article can be found online at http://dx. doi.org/10.1016/j.seares.2015.02.005.

\section{Acknowledgments}

Thank goes to our technical assistants Annika Schroer and Anja Nicolaus at AWI for assistance with the molecular analyses and general support in the laboratory. We would like to thank Kerstin Heymann from Helmholtz-Zentrum Geesthacht for performing the HPLC pigment analyses, as well as Mirko Lunau from AWI who helped with the flow cytometry. The study was performed within the COSYNA-project (Coastal Observation Systems for Northern and Arctic Seas) in cooperation with the Young Investigator Group PLANKTOSENS, which is funded by the Initiative and Networking Fund of the Helmholtz Association (VH-NG-500). Thank goes also to three anonymous reviewers who helped to improve the manuscript with their comments.

\section{References}

Agawin, N.S.R., Duarte, C.M., Agustí, S., 2000. Nutrient and temperature control of the contribution of picoplankton to phytoplankton biomass and production. Limnol Oceanogr. 45 (3), 591-600.

Banse, K., 1977. Determining the carbon-to-chlorophyll ratio of natural phytoplankton Mar. Biol. 41 (3), 199-212. http://dx.doi.org/10.1007/BF00394907.

Baretta, J.W., Ebenhöh, W., Ruardij, P., 1995. The European regional seas ecosystem model, a complex marine ecosystem model. Neth. J. Sea Res. 33 (3-4), 233-246.

Bent, S.J., Pierson, J.D., Forney, L.J., 2007. Measuring species richness based on microbial community fingerprints: the emperor has no clothes. Appl. Environ. Microbiol. 73 (7), 2399.

Brussaard, C.P.D., 2004. Viral control of phytoplankton populations - a review. J. Eukaryot. Microbiol. 51 (2), 125-138.

Calbet, A., Landry, M.R., 2004. Phytoplankton growth, microzooplankton grazing, and carbon cycling in marine systems. Limnol. Oceanogr. 49 (1), 51-57.

Carlsson, P., Granéli, E., 1993. Availability of humic bound nitrogen for coastal phytoplankton. Estuar. Coast. Shelf Sci. 36 (5), 433-447. http://dx.doi.org/10.1006/ecss. 1993.1026.

Chisholm, S.W., 1992. Phytoplankton size. In: Falkowski, P., Woodhead, A. (Eds.), Primary Productivity and Biogeochemical Cycles in the Sea. Plenum Press, New York, pp. 213-237.

Cullen, J.J., 1985. Diel vertical migration by dinoflagellates: roles of carbohydrate metabolism and behavioral flexibility. Contrib. Mar. Sci. 27, 135-152.

Danovaro, R., Luna, G.M., Dell'Anno, A., Pietrangeli, B., 2006. Comparison of two fingerprinting techniques, terminal restriction fragment length polymorphism and automated ribosomal intergenic spacer analysis, for determination of bacterial diversity in aquatic environments. Appl. Environ. Microbiol. 72 (9), 5982-5989. http://dx.doi. org/10.1128/aem. 01361-06.

De Bruin, A., Ibelings, B.W., Van Donk, E., 2003. Molecular techniques in phytoplankton research: from allozyme electrophoresis to genomics. Hydrobiologia 491, 47-63.

Díez, B., Pedrós-Alió, C., Massana, R., 2001. Study of genetic diversity of eukaryotic picoplankton in different oceanic regions by small-subunit rRNA gene cloning and sequencing. Appl. Environ. Microbiol. 67 (7), 2932-2941.

Dortch, Q., 1982. Effect of growth conditions on accumulation of internal nitrate, ammonium, amino acids, and protein in three marine diatoms. J. Exp. Mar. Biol. Ecol. 61 (3), 243-264. http://dx.doi.org/10.1016/0022-0981(82)90072-7.

Ducrotoy, J.P., Elliott, M., De Jonge, V.N., 2000. The North Sea. Mar. Pollut. Bull. 41 (1-6), $5-23$.

Falkowski, P., Kiefer, D.A., 1985. Chlorophyll a fluorescence in phytoplankton: relationship to photosynthesis and biomass. J. Plankton Res. 7 (5), 715-731. http://dx.doi.org/10. 1093/plankt/7.5.715

Fechner, L.C., Vincent-Hubert, F., Gaubert, P., Bouchez, T., Gourlay-France, C., TusseauVuillemin, M.H., 2010. Combined eukaryotic and bacterial community fingerprinting of natural freshwater biofilms using automated ribosomal intergenic spacer analysis. FEMS Microbiol. Ecol. 74 (3), 542-553. http://dx.doi.org/10.1111/j.1574-6941.2010. 00968.x.

Field, C.B., Behrenfeld, M.J., Randerson, J.T., Falkowski, P., 1998. Primary production of the biosphere: integrating terrestrial and oceanic components. Science 281 (5374), 237-240. http://dx.doi.org/10.1126/science.281.5374.237.

Fogg, G.E., 1991. Tansley Review.30. The phytoplanktonic ways of life. New Phytol. 118 (2), 191-232. http://dx.doi.org/10.1111/j.1469-8137.1991.tb00974.x

Freund, J.A., Grüner, N., Brüse, S., Wiltshire, K.H., 2012. Changes in the phytoplankton community at Helgoland, North Sea: lessons from single spot time series analyses. Mar. Biol. 159 (11), 2561-2571. http://dx.doi.org/10.1007/s00227-012-2013-7.

Gao, Y.H., Chen, C.P., Li, Y., 2003. Marine nanoplanktonic diatoms from the coastal waters of Hong Kong. In: Morton, B. (Ed.), Perspectives on Marine Environmental Change in Hong Kong 1977-2001. Hong Kong University Press, Hong Kong.

Gaul, W., Antia, A.N., 2001. Taxon-specific growth and selective microzooplankton grazing of phytoplankton in the Northeast Atlantic. J. Mar. Syst. 30 (3-4), 241-261.

Geider, R.J., 1987. Light and temperature-dependence of the carbon to chlorophyll-a ratio in microalgae and cyanobacteria - implications for physiology and growth of phytoplankton. New Phytol. 106 (1), 1-34. http://dx.doi.org/10.1111/j.1469-8137.1987. tb04788.x.

Gescher, C., Metfies, K., Frickenhaus, S., Knefelkamp, B., Wiltshire, K.H., Medlin, L.K., 2008 Feasibility of assessing the community composition of prasinophytes at the 
Helgoland roads sampling site with a DNA microarray. Appl. Environ. Microbiol. 74 (17), 5305-5316. http://dx.doi.org/10.1128/aem. 01271-08.

Gillbricht, M., 1988. Phytoplankton and nutrients in the Helgoland region. Helgoländer Meeresun. 42 (3-4), 435-467.

Grasshoff, K., Ehrhardt, M., Kremling, K., 1983. Methods of Seawater Analysis. Verlag Chemie, Weinheim, Germany.

Hagmeier, E., Bauerfeind, E., 1990. Phytoplankton. In: Lozán, J.L., Lenz, W., Rachor, E., Watermann, B., von Westernhagen, H. (Eds.), Warnsignale aus der Nordsee. Parey, Berlin, Hamburg.

Hallegraeff, G.M., 1977. A comparison of different methods used for the quantitative evaluation of biomass of freshwater phytoplankton. Hydrobiologia 55 (2), 145-165.

Hammer, Ø., Harper, D.A.T., Ryan, P.D., 2001. Past: Paleontological statistics software package for education and data analysis. Palaeontol. Electron. 4 (1), 9.

Hesse, K., Liu, Z., Schaumann, K., 1989. Phytoplankton and fronts in the German Bight. Sci. Mar. (Barcelona) 53 (2-3).

Hickel, W., 1998. Temporal variability of micro- and nanoplankton in the German Bight in relation to hydrographic structure and nutrient changes. ICES J. Mar. Sci. 55 (4), 600-609. http://dx.doi.org/10.1006/jmsc.1998.0382.

Hillebrand, H., Durselen, C.D., Kirschtel, D., Pollingher, U., Zohary, T., 1999. Biovolume calculation for pelagic and benthic microalgae. J. Phycol. 35 (2), 403-424.

Hoppenrath, M., 2004. A revised checklist of planktonic diatoms and dinoflagellates from Helgoland (North Sea, German Bight). Helgol. Mar. Res. 58 (4), 243-251. http://dx. doi.org/10.1007/s10152-004-0190-6.

Hoppenrath, M., Beszteri, B., Drebes, G., Halliger, H., Van Beusekom, J.E.E., Janisch, S., Wiltshire, K.H., 2007. Thalassiosira species (Bacillariophyceae, Thalassiosirales) in the North Sea at Helgoland (German Bight) and Sylt (North Frisian Wadden Sea) a first approach to assessing diversity. Eur. J. Phycol. 42 (3), 271-288.

IOC/UNESCO, IMO, FAO, UNDP, 2011. A Blueprint for Ocean and Coastal Sustainability. IOC/UNESCO, Paris.

Jiménez, F., Rodríguez, J., Bautista, B., Rodríguez, V., 1987. Relations between chlorophyll, phytoplankton cell abundance and biovolume during a winter bloom in Mediterranean coastal waters. J. Exp. Mar. Biol. Ecol. 105 (2-3), 161-173.

Kirk, J.T.O., 1994. Light \& Photosynthesis in Aquatic Ecosystems. 2nd ed. Cambridge University Press, Cambridge.

Knefelkamp, B., 2009. An Investigation of the Eukaryotic Picoplankton Community in the German North Sea by Different Methods. (PhD thesis). University Bremen, Bremen.

Kochzius, M., Kappel, K., Döbitz, L., Silkenbeumer, N., Nölte, M., Weber, H., Hjörleifsdottir, S., Marteinsson, V., Hreggvidsson, G., Planes, S., Tinti, F., Magoulas, A., Vazquez, E.G., Turan, C., Medlin, L., Metfies, K., Gescher, C., Cariani, A., Landi, M., Hervet, C., Falgueras, D.C., Antoniou, A., Bertasi, F., Srujana, C., Blohm, D., 2007. The "fish \& chips" project: microarrays as a tool for the identification of marine organisms in biodiversity and ecosystem research. OCEANS 2007 - Europe.

Kovacs, A., Yacoby, K., Gophna, U., 2010. A systematic assessment of automated ribosomal intergenic spacer analysis (ARISA) as a tool for estimating bacterial richness. Res. Microbiol. 161 (3), 192-197. http://dx.doi.org/10.1016/j.resmic.2010. 01.006.

Kraberg, A.C., Carstens, K., Peters, S., Tilly, K., Wiltshire, K.H., 2012. The diatom Mediopyxis helysia Kühn, Hargreaves \& Halliger 2006 at Helgoland Roads: a success story? Helgol. Mar. Res. 66 (3), 463-468.

Li, W.K.W., Dickie, P.M., 2001. Monitoring phytoplankton, bacterioplankton, and virioplankton in a coastal inlet (Bedford Basin) by flow cytometry. Cytometry 44 (3), 236-246. http://dx.doi.org/10.1002/1097-0320(20010701)44:3<236::AIDCYTO1116>3.0.CO;2-5.

Lindén, E., Kuosa, H., 2004. Effects of grazing and excretion by pelagic mysids (Mysis spp.) on the size structure and biomass of the phytoplankton community. Hydrobiologia 514, 73-78.

Liu, W.T., Marsh, T.L., Cheng, H., Forney, L.J., 1997. Characterization of microbial diversity by determining terminal restriction fragment length polymorphisms of genes encoding 16S rRNA. Appl. Environ. Microbiol. 63 (11), 4516-4522.

Llewellyn, C.A., Gibb, S.W., 2000. Intra-class variability in the carbon, pigment and biomineral content of prymnesiophytes and diatoms. Mar. Ecol. Prog. Ser. 193, 33-44.

Loebl, M., Colijn, F., van Beusekom, J.E.E., Baretta-Bekker, J.G., Lancelot, C., Philippart, C.J.M., Rousseau, V., Wiltshire, K.H., 2009. Recent patterns in potential phytoplankton limitation along the Northwest European continental coast. J. Sea Res. 61 (1-2) 34-43.

Lund, J.W.G., Kipling, C., Le Cren, E.D., 1958. The inverted microscope method of estimating algal numbers and the statistical basis of estimations by counting. Hydrobiologia 11 (2), 143-170.

MacIntyre, J., Cullen, J., Cembella, A., 1997. Vertical migration, nutrition and toxicity in the dinoflagellate Alexandrium tamarense. Mar. Ecol. Prog. Ser. 148 (1), 201-216.

Mackey, M.D., Mackey, D.J., Higgins, H.W., Wright, S.W., 1996. CHEMTAX - a program for estimating class abundances from chemical markers: application to HPLC measurements of phytoplankton. Mar. Ecol. Prog. Ser. 144 (1-3), 265-283.

Magurran, A.E., 2004. Measuring Biological Diversity. Blackwell Publishers, Oxford.

Medlin, L., Metfies, K., Mehl, H., Wiltshire, K., Valentin, K., 2006. Picoeukaryotic plankton diversity at the Helgoland time series site as assessed by three molecular methods. Microb. Ecol. 52 (1), 53-71.

Menden-Deuer, S., Lessard, E.J., 2000. Carbon to volume relationships for dinoflagellates, diatoms, and other protist plankton. Limnol. Oceanogr. 45 (3), 569-579.

Metfies, K., Medlin, L., 2005. Ribosomal RNA probes and microarrays: their potential use in assessing microbial biodiversity. In: Zimmer, E.A., Roalson, E.H. (Eds.), Methods in Enzymology. Elsevier Academic Press, San Diego, pp. 258-278.

Metfies, K., Medlin, L.K., 2007. Refining cryptophyte identification with DNA-microarrays. J. Plankton Res. 29 (12), 1071-1075.

Metfies, K., Gescher, C., Frickenhaus, S., Niestroy, R., Wichels, A., Gerdts, G., Knefelkamp, B Wiltshire, K., Medlin, L., 2010. Contribution of the class cryptophyceae to phytoplankton structure in the German Bight. J. Phycol. 46 (6), 1152-1160. http:// dx.doi.org/10.1111/j.1529-8817.2010.00902.x.

Montagnes, D.J.S., Berges, J.A., Harrison, P.J., Taylor, F.J.R., 1994. Estimating carbon, nitrogen, protein, and chlorophyll-a from volume in marine phytoplankton. Limnol. Oceanogr. 39 (5), 1044-1060.

Moon-van der Staay, S.Y., De Wachter, R., Vaulot, D., 2001. Oceanic 18S rDNA sequences from picoplankton reveal unsuspected eukaryotic diversity. Nature 409 (6820), 607-610.

Morel, A., Bricaud, A., 1981. Theoretical results concerning light absorption in a discrete medium, and application to specific absorption of phytoplankton. Deep Sea Res. Part A 28 (11), 1375-1393.

Nelson, T.A., Holmes, S., Alekseyenko, A.V., Shenoy, M., Desantis, T., Wu, C.H., Andersen, G.L., Winston, J., Sonnenburg, J., Pasricha, P.J., Spormann, A., 2011. PhyloChip microarray analysis reveals altered gastrointestinal microbial communities in a rat model of colonic hypersensitivity. Neurogastroenterol. Motil. 23 (2), 169-178. http://dx.doi. org/10.1111/j.1365-2982.2010.01637.x.

Not, F., Zapata, M., Pazos, Y., Campaña, E., Doval, M., Rodríguez, F., 2007. Size-fractionated phytoplankton diversity in the NW Iberian coast: a combination of microscopic, pigment and molecular analyses. Aquat. Microb. Ecol. 49 (3), 255-265.

Not, F., Latasa, M., Marie, D., Cariou, T., Vaulot, D., Simon, N., 2004. A single species, Micromonas pusilla (Prasinophyceae), dominates the eukaryotic picoplankton in the Western English Channel. Appl. Environ. Microbiol. 70 (7), 4064-4072.

Novarino, G., Mills, D.K., Hannah, F., 1997. Pelagic flagellate populations in the southern North Sea, 1988-89. I. Qualitative observations. J. Plankton Res. 19 (8), 1081-1109. http://dx.doi.org/10.1093/plankt/19.8.1081.

Olson, R.J., Vaulot, D., Chisholm, S.W., 1985. Marine phytoplankton distributions measured using shipboard flow cytometry. Deep Sea Res. Part A 32 (10), 1273-1280. http://dx.doi.org/10.1016/0198-0149(85)90009-3.

Peeters, J.C.H., Peperzak, L., 1990. Nutrient limitation in the North Sea: a bioassay approach. Neth. J. Sea Res. 26 (1), 61-73.

Peperzak, L., 2010. An objective procedure to remove observer-bias from phytoplankton time-series. J. Sea Res. 63 (2), 152-156.

Petersen, W., Schroeder, F., Bockelmann, F.D., 2011. FerryBox - application of continuous water quality observations along transects in the North Sea. Ocean Dyn. 61 (10), 1541-1554. http://dx.doi.org/10.1007/s10236-011-0445-0.

Phinney, D.A., Cucci, T.L., 1989. Flow cytometry and phytoplankton. Cytometry 10 (5), 511-521.

Prakash, A., Rashid, M., 1968. Influence of humic substances on the growth of marine phytoplankton: dinoflagellates. Limnol. Oceanogr. 13 (3), 598-601.

Radach, G., 1992. Ecosystem functioning in the German Bight under continental nutrient inputs by rivers. Estuaries 15 (4), 477-496. http://dx.doi.org/10.2307/1352392.

Reid, P.C., Lancelot, C., Gieskes, W.W.C., Hagmeier, E., Weichart, G., 1990. Phytoplankton in the North Sea and its dynamics - a review. Neth. J. Sea Res. 26 (2-4), 295-331.

Rhodes, C.J., Truscott, J.E., Martin, A.P., 2008. Viral infection as a regulator of oceanic phytoplankton populations. J. Mar. Syst. 74 (1-2), 216-226.

Riegman, R., Kuipers, B.R., Noordeloos, A.A.M., Witte, H.J., 1993. Size-differential control of phytoplankton and the structure of plankton communities. Neth. J. Sea Res. 31 (3), 255-265.

Sabetta, L., Basset, A., Spezie, G., 2008. Marine phytoplankton size-frequency distributions: spatial patterns and decoding mechanisms. Estuar. Coast. Shelf Sci. 80 (1), 181-192.

Schlitzer, R., 2012. Ocean Data View http://odv.awi.de.

Schlüter, L., Mohlenberg, F., Havskum, H., Larsen, S., 2000. The use of phytoplankton pigments for identifying and quantifying phytoplankton groups in coastal areas: testing the influence of light and nutrients on pigment/chlorophyll a ratios. Mar. Ecol. Prog. Ser. 192, 49-63.

Schlüter, M.H., Kraberg, A., Wiltshire, K.H., 2012. Long-term changes in the seasonality of selected diatoms related to grazers and environmental conditions. J. Sea Res. 67 (1), 91-97. http://dx.doi.org/10.1016/j.seares.2011.11.001.

Sessitsch, A., Hackl, E., Wenzl, P., Kilian, A., Kostic, T., Stralis-Pavese, N., Sandjong, B.T., Bodrossy, L., 2006. Diagnostic microbial microarrays in soil ecology. New Phytol. 171 (4), 719-736. http://dx.doi.org/10.1111/j.1469-8137.2006.01824.x.

Stavn, R.H., Rick, H.J., Falster, A.V., 2009. Correcting the errors from variable sea salt retention and water of hydration in loss on ignition analysis: implications for studies of estuarine and coastal waters. Estuar. Coast. Shelf Sci. 81 (4), 575-582.

Stehouwer, P.P., Liebich, V., Peperzak, L., 2013. Flow cytometry, microscopy, and DNA analysis as complementary phytoplankton screening methods in ballast water treatment studies. J. Appl. Phycol. 25 (4), 1047-1053.

Tillmann, U., Rick, H.J., 2003. North Sea phytoplankton: a review. Senckenberg. Marit. 33 (1-2), 1-69.

Tilman, D., Kilham, S.S., Kilham, P., 1982. Phytoplankton community ecology: the role of limiting nutrients. Annu. Rev. Ecol. Syst. 13, 349-372. http://dx.doi.org/10.1146/ annurev.es.13.110182.002025.

Utermöhl, H., 1958. Zur Vervollkommnung der quantitativen Phytoplankton-Methodik. Internationale Vereinigung für theoretische und angewandte Limnologie Mitteilungen, vol 9. Schweizerbartsche Verlagsbuchandlung, Stuttgart.

Vaulot, D., Eikrem, W., Viprey, M., Moreau, H., 2008. The diversity of small eukaryotic phytoplankton $(<=3 \mathrm{mu} \mathrm{m})$ in marine ecosystems. FEMS Microbiol. Rev. 32 (5), 795-820. http://dx.doi.org/10.1111/j.1574-6976.2008.00121.x.

Vives-Rego, J., Lebaron, P., Nebe-von Caron, G., 2000. Current and future applications of flow cytometry in aquatic microbiology. FEMS Microbiol. Rev. 24 (4), 429-448. http://dx.doi.org/10.1111/j.1574-6976.2000.tb00549.x.

Wheeler, P., 1983. Phytoplankton nitrogen metabolism. In: Carpenter, E.J., Capone, D.G. (Eds.), Nitrogen in the Marine Environment. Academic Press, New York, pp. 309-346.

Whittaker, R.H., 1960. Vegetation of the Siskiyou Mountains, Oregon and California. Ecol. Monogr. 30 (3), 279-338. http://dx.doi.org/10.2307/1943563. 
Wiltshire, K.H., Dürselen, C.D., 2004. Revision and quality analyses of the Helgoland Reede long-term phytoplankton data archive. Helgol. Mar. Res. 58 (4), 252-268. http://dx. doi.org/10.1007/s10152-004-0192-4.

Wiltshire, K.H., Manly, B.F.J., 2004. The warming trend at Helgoland Roads, North Sea: phytoplankton response. Helgol. Mar. Res. 58 (4), 269-273. http://dx.doi.org/10. 1007/s10152-004-0196-0.

Wiltshire, K.H., Kraberg, A., Bartsch, I., Boersma, M., Franke, H.D., Freund, J., Gebühr, C., Gerdts, G., Stockmann, K., Wichels, A., 2010. Helgoland Roads, North Sea: 45 years of change. Estuar. Coasts 33 (2), 295-310. http://dx.doi.org/10.1007/s12237-009-9228-y.

Wolf, C., Frickenhaus, S., Kilias, E.S., Peeken, I., Metfies, K., 2013. Regional variability in eukaryotic protist communities in the Amundsen Sea. Antarct. Sci. 1-11 http://dx. doi.org/10.1017/S0954102013000229 (FirstView).

Wollschläger, J., Nicolaus, A., Wiltshire, K.H., Metfies, K., 2014. Assessment of North Sea phytoplankton via molecular sensing: a method evaluation. J. Plankton Res. http:// dx.doi.org/10.1093/plankt/fbu003.
Yachi, S., Loreau, M., 1999. Biodiversity and ecosystem productivity in a fluctuating environment: the insurance hypothesis. Proc. Natl. Acad. Sci. 96 (4), 1463-1468. http://dx.doi.org/10.1073/pnas.96.4.1463.

Zapata, M., Rodriguez, F., Garrido, J.L., 2000. Separation of chlorophylls and carotenoids from marine phytoplankton: a new HPLC method using a reversed phase C-8 column and pyridine-containing mobile phases. Mar. Ecol. Prog. Ser. 195, 29-45. http://dx. doi.org/10.3354/meps195029.

Zapata, M., Fraga, S., Rodríguez, F., Garrido, J.L., 2012. Pigment-based chloroplast types in dinoflagellates. Mar. Ecol. Prog. Ser. 465, 33-52. http://dx.doi.org/10. 3354/meps09879. 